\section{A. ARS BILDUMA \\ ISSN 1989-9262 \\ UPV/EHU Press}

ARSBILDUMA (CC BY-NC-ND 4.0)

https://doi.org/10.1387/ars-bilduma.20893 BIBLID [(2019), 9; 113-136]

Recibido: 01/03/2019 Aceptado: 24/05/2019

\section{FERNANDO R. BARTOLOMÉ GARCÍA}

Universidad del País Vasco (UPV/EHU)

Facultad de Letras

Paseo de la Universidad, 5

01006, Vitoria-Gasteiz (Álava)

fernandor.bartolome@ehu.eus

ORCID: 0000-0003-3802-3585

Este artículo ha sido realizado en el marco del proyecto de investigación del Ministerio de Economía y Competitividad del Gobierno de España HAR2017-84226-C6-5-P "Los cambios de la modernidad y las resistencias al cambio. Redes sociales, transformaciones culturales y conflictos, siglos XVI-XIX”.

Grupo de Investigación del Sistema Universitario Vasco IT896-16: "Sociedad, Poder y Cultura, siglos XIV-XVIII”.

\title{
LA FÁBRICA DE PAPELES PINTADOS SANTA ISABEL DE VITORIA A MEDIADOS DEL SIGLO XIX
}

\author{
THE SANTA ISABEL OF VITORIA PAINTED PAPER FACTORY IN THE \\ MID-NINETEENTH CENTURY
}

\author{
SANTA IXABEL PAPER MARgotuen LANTEgia (GASTEIZ) XiX. MENDEKo \\ ERDIALDEAN
}

\section{RESUMEN}

La fábrica de papeles pintados de Santa Isabel de Vitoria fue fundada en 1846 y, aunque no tuvo una vida productiva muy larga se convirtió en uno de los establecimiento artísticos artesanales más importantes del País Vasco en esos años. Fue diseñada imitación de las francesas, dotada de maquinaria moderna y de operarios cualificados, y gracias a ello consiguió producir papeles pintados de gran calidad y variedad. Lamentablemente, no pudo superar la competencia extranjera y la presión fiscal sobre la materia prima y los productos elaborados, lo que la llevó a su rápida desaparición.

\section{PALABRAS CLAVE}

Fábrica, Santa Isabel, Vitoria, papel pintado, estampado.

\section{ABSTRACT}

The Santa Isabel painted paper factory of Vitoria was founded in 1846 and, even if did not have a long production life, it became one of the most relevant artistic crafts establishments of the Basque Country at the time. It was designed following French factories, equipped with modern machinery and qualified workers, producing a great variety of quality painted paper. Unfortunately, it could not overcome foreign competitiveness as well as the tax burden over raw materials and prepared products, which prompted a quick demise.

\section{KEYWORDS}

Factory, Santa Isabel, Vitoria, painted paper, pattern.

\section{LABURPENA}

Gasteizko Santa Ixabeleko paper margotuen lantegia 1846an sortu zen, eta nahiz eta oso bizitza luzea ez izan, Euskal Herriko artisau-enpresa garrantzitsuenetariko bat izatera ailegatu zen. Frantziarren erara diseinaturik, makina modernoei eta langile gaituei esker kalitate eta eredu askotariko paper margotuak egin zituen. Zoritzarrez, ez zen gai izan atzerriko konpetentziari et lehengaien eta produktuen gaineko presio fiskalari aurre egiteko. Hau guztia dela eta, fabrika laster desagertu zen.

\section{GAKO-HITZAK}

Hitz gakoak: lantegia, Santa Ixabel, Vitoria-Gasteiz, paper margotua, estanpatua. 


\section{INTRODUCCIÓN}

Aunque los papeles pintados o estampados van adquiriendo cada vez más relevancia entre los profesionales dedicados al arte y la restauración, todavía no deja de ser una especialidad poco conocida y valorada en España. Cada día son más los conjuntos y restos descubiertos y recuperados para su disfrute y valoración, pero nunca serán suficientes para darnos cuenta de la magnitud y la importancia que tuvieron a lo largo de la Edad Moderna y Contemporánea ${ }^{1}$. Lamentablemente los papeles pintados son fácilmente degradables por factores internos, derivados de sus propios materiales y técnicas, o externos, puesto que a su fragilidad se unen los deterioros del propio muro arquitectónico que los ampara. Además los constantes cambios de gusto a los que han estado sometidos han facilitado su rápida desaparición, por lo que casi podemos considerarlos como arte efímero dependientes de las modas imperantes ${ }^{2}$. Hasta que se generalizó su uso fueron objetos artísticos muy exclusivos, a los que solo pudieron acceder las élites más cosmopolitas, que buscaban reforzar su posición y prestigio social en la comunidad a través del buen gusto que suponía

1 En el País Vasco se han dado a conocer importantes conjuntos de papeles pintados Vid.: RODRÍGUEZ LASO, M. ${ }^{a}$ D.; CANALS AROMI, M. ${ }^{a}$ T.: "Localización de papeles pintados del siglo XIX en España. Restauración del papel pintado panorámico Vistas de España”, 24. ${ }^{\circ}$ Congreso IPH, Oporto, 1998, pp 280-286. CANALS AROMí, M. T. "Principales centros de fabricación de papel pintado en España a mediados del siglo XIX", Actas del IV Congreso Nacional de Historia del Papel en España, Cuenca, Asociación Hispánica de Historiadores del papel, 2001, pp. 73-80. RODRÍGUEZ LASO M.a D.: "Restauración de papeles pintados "panorámicas" en el País Vasco: la caza de Compiègne", Akobe, 3, 2002, pp. 25-27. RODRÍGUEZ LASO, M. ${ }^{a}$ D.: El arte y la ciencia de la mano. La recuperación de papeles pintados históricos. Bilbao, Universidad del País Vasco, 2004. RODRÍGUEZ LASO, M. a D.: "El pape como soporte del papel pintado", Actas del VI Congreso Nacional de la historia del Papel en España, Valencia Conselleria de Cultura Educació i Esport 2005, pp 89-91. RODRÍGUEZ L ASO M a D. "Los papes ping papeles pitad La torre-palacio de los Varona. historia y patrimonio. Vitoria-Gasteiz, Diputación Foral de Alava, 2009. MARTIARENA, X.: "Papeles pintados, 1835. Eskoriatza, Aretxabaleta, Donostia, Villanañe y Azkoitia". www.xabimartia.blogspot.com.es/ (Consultado el 12/03/2019). DE PABLO ALVA, R.: Los papeles pintados de la torre de los Varona en Villanañe (Álava), Trabajo fin de grado, curso 2018-19 (bajo la dirección de Fernando R. Bartolomé García). https://addi.ehu.es/handle/10810/30143 (consultado el 15/03/1019). Quiero agradecer las orientaciones dadas por José Cortés Arjona, técnico del departamento de documento gráfico y fotográfico de Servicio de Restauración de la Diputación Foral de Álava.

RODRÍCUEZ LASO, Ma D. CANALS AROMI, Ma T. "Localización de papeles. op. cit. pp. 280281. RODRÍGUEZ LASO Ma D. El arte y ciencia de lo mano. La recuperacín de papes pintados históricos. Bilbao Universidad del Pás Vasco, 2004, p. 13 . Nos presenta las degradion les que afectan al papel pintado. ROSE-DE VIEJO, I.: La Real Fábrica de Papales Pintados de Madrid (1786-1836), Madrid, Cátedra, 2015, p. 113. disponer en las habitaciones de su palacio bellos papeles decorativos y otros objetos de lujo. Este afán de notoriedad de las clases más acomodadas favoreció la importación e incluso el contrabando de papeles pintados venidos de las principales fábricas europeas.

Los orígenes de la fabricación de papel pintado deben situarse en Oriente desde donde llegaron a Europa a través de las habituales vías comerciales. Estos productos se conocían como indias y su ejecución y técnica nada tienen que ver con los que posteriormente se realizaran en occidente $^{3}$. A España llegaron mediante la ruta de Oriente que conectaba Manila, Acapulco, Veracuz y Sevilla y posteriormente la inaugurada por la Real Compañía de Filipinas que unía Manila y Cádiz. A través de estas vías comerciales se importaban productos exóticos de gran valor como especias, textiles, marfil, jade, muebles, porcelanas y otros objetos artístico destinados a los mercados españoles y europeos. Las primeras muestras conocidas de papeles decorados fabricados en Europa son de siglo XVI y son considerados como los precedentes del papel pintado. Fueron destinados principalmente a cubrir puertas, vigas, artesonados, muebles u otros objetos de pequeño tamaño ${ }^{4}$. A finales del siglo XVII los fabricantes europeos estaban ya desarrollando papel como revestimiento mural. Poco a poco se convirtió en un elemento decorativo imprescindible en las viviendas de las élites, por lo que rápidamente surgió un gran interés por elaborar estos productos evitando las importaciones de oriente ${ }^{5}$. Se inicia aquí la gran andadura en la fabricación de papeles pintados en Europa, que alcanzará a finales del siglo XVIII un momento álgido en la producción y perfección técnica. Surgieron fábricas tan importantes como la fundada en Rixheim (Francia) por Juan Zuber en 1790 o la de los hermano Joseph y Pierre Dufour en la región de Borgoña ${ }^{6}$. Francia, Inglaterra, Alemania, Suiza, Bélgica y Holanda fueron algunos de los países punteros en la creación y producción de papeles pintados en Europa ${ }^{7}$.

HOSKINS, L. (ed.): The papered Wall. The history, petterns and techniques of wallpaper, London, Thames and Hudson, 1994. RODRIGUEZ LASO, D. (et. al.): "El papel como soporte...", op. cit., pp. 89-92.

RENFER, CH.: "Fladerpapier et papiers de décor imprimés du XVIe siècle - Aperçu des fonds suisses" en THOMSON, H. B. (Dir.): Papiers peints, poésie des murs. Les collections du Musée National Suisse, Zürich, Musée National de Suisse, 2010, pp. 125-137.

5 RUIZ ALCÓN M.a T.: "Papeles pintados" en BONET CORREA, A.: Historia de las Artes Aplicadas e Industriales en España. Madrid, Cátedra, 1987, pp. 423-425. HOSKINS, L. (ed.): op. cit., p. 13

6 LA HOUGUE, V.: "Les fabricants de papiers peint à Lyon de la fin du XVIIIe siècle", Bulletin de la Société Historique, Archéologique et Littéraire de Lyon, XXXII, 2002, pp. 13-48. RUIZ ALCÓN M. ${ }^{a}$ T.: "Papeles pintados"..., op. cit., p. 423. RODRÍGUEZ LASO, M. ${ }^{a}$ D.: "Los papeles pintados en Euskadi..., op. cit.

7 Para mayor información vid.: TEYNAC, F.; NOLOT, P.; VIVIEN, J-D.: Le monde du papier peint, París, Berger-Levrault, 1981. JACQUÉ, B., (et. al.): Les papiers peints en arabesques de la fin du XVIIIe siècle, París, Martinière, 1995. VV. AA.: French Scenic wallpaper 1795-1865, Paris, Musée des Arts Décoratifs, 
El éxito adquirido fue incrementándose a lo largo del siglo XIX con importantes novedades técnicas y decorativas. Una de las aportaciones más destacadas fue la creación de la impresión mecánica patentada y desarrollada en 1839 por la firma inglesa Potters \& Ross dejando la estampación manual tan solo para productos de lujo. Ésta mecanización permitió una producción en masa y una bajada de los precios y calidades respecto a los productos artesanales tradicionales, lo que ayudó a que este producto se popularizara entre la sociedad burguesa del momento. Supuso la aparición de nuevas fábricas y un importante desarrollo técnico con nuevos y complejos procedimientos que fueron implantándose a lo largo de los siglos XIX y XX .

En España también se vivió un proceso similar en el desarrollo de la fabricación y uso de papeles pintados pero siempre con retraso respecto de los países punteros europeos. Ya en el siglo XVII se documentan algunas fábricas y almacenes de venta, pero sin duda la más importante fue la Real Fábrica de Papeles Pintados de Madrid (1786-1836) ${ }^{9}$. Su creación responde a la política fundacional de manufacturas por parte de la monarquía borbónica y al pensamiento ilustrado que imbuía a la sociedad del momento. El interés era doble, por un lado dar prestigio a la Corona y por otro potenciar una política proteccionista en aras a evitar la importación de objetos de lujo ${ }^{10}$. A mediados del siglo XIX se advierte un gran impulso en la producción y expansión del papel pintado en España con la aparición de importantes fábricas. Entre las más conocidas están la de Sebastián Waiss de La Coruña, Santa Isabel de Vitoria, Diego Delicado y Cia. de Torre del Mar de Málaga, Sres. Berlschinger y Codina de Barcelona, Viuda de Ribed e Hijo de Villava o Las Maravillas de Madrid ${ }^{11}$

Flammarion, 1990. HOSKINS, L. (ed.): op. cit., JACQUÉ, J.; WISSE, G.: Le murmure des murs, quatre siècles d'histoire du papier peint, Bruxelles, Studio, 2001. THIBAUT-POMERANTZ, C.: Wallpaper, history of style and trends, París, Flammarion, 2009. THOMSON, H. B. (Dir.): Papiers peints, poésie des murs. Les collections du Musée National Suisse, Zürich, Musée national de Suisse, 2010.

8 RODRÍGUEZ LASO, M. ${ }^{a}$ D.: El arte y la ciencia de la mano..., op. cit., p. 11. Entre las técnicas desarrolladas destacan la serigrafía, heliograbado, flexograbado y fotograbado.

9 CANALS I AROMÍ M. ${ }^{a}$ T.: Els papers pintats i les arts decoratives, Barcelona, Museu de les arts decoratives, 2003. CANALS AROMÍ, M. a T.: "Real Fábrica de papeles pintados, 1788-1834", en TORREGUITART BÚA, S., (coord.): Jornadas sobre Reales Fábricas, La Granja de San Ildefonso. Cuenca, Fundación Centro Nacional del Vidrio, 2004, pp. 395-405. ROSE-DE VIEJO, I.: op. cit. SANZ DE MIGUEL, C. "La revalorización del Arte del papel pintado en una de las últimas manufacturas regias del Antiguo Régimen español", Revista Historia Autónoma, n. ${ }^{\circ}$ 10, 2017, pp. 219-222.

10 DE PABLOS Y VIEJO, E.: HERRERO CARRETERO, C.: MANUUECO SANTURTUN, C.: Manufactura Reales españolas, Madrid, Fundación Fondo de Cultura de Sevilla, Caja Madrid, 1993. CANALS AROMÍ, M. ${ }^{a}$ T.: "Real Fábrica de papeles pintados..., op. cit., p. 396. ROSE-DE VIEJO, I.: op. cit. SANZ DE MIGUEL, C.: op. cit., pp. 219-222.

11 CANALS AROMI, M. T.: "Principales centros..., op. cit., pp. 73-80. ROSE-DE VIEJO, I.: op. cit., pp.

\section{LA FÁbRICA SANTA ISABEL. PUESTA EN MARCHA Y PRIMEROS}

\section{CONTRATIEMPOS}

En este contexto nacía la fábrica de papel pintado, "satinado, apañado, aterciopelado y dorado" de Santa Isabel de Vitoria, iniciando su andadura en agosto de 1846, "montada sin lujo, pero con mucho conocimiento ${ }^{12}$ ". Se situaba inicialmente a las afueras de la ciudad, en una zona sin apenas urbanizar (Fig. 1). Allí permaneció hasta 1860, año en el que tuvo que trasladarse ligeramente al construir la calle Oriente, quedando situada junto a la primitiva plaza de toros y frente a la nueva cárcel ${ }^{13}$ (Fig. 2-3). Este establecimiento de fabricación de papel pintado fue fundado por cinco socios: José María Villaoz, Manuel Ordozgoiti, Saturnino de Ormilugue, Valentín de Echevarría y Gregorio Cortázar que aportaron medio millón de reales para poner en marcha este negocio ${ }^{14}$. Se trataba de una sociedad mercantil de la que podían formar parte otros accionistas a través de la compra y venta de las mismas ${ }^{15}$. El socio propietario fue José María Villaoz un importante emprendedor prestamista y empresario que participó en innumerables proyectos mercantiles, como en la sociedad minera Unión Alavesa o el ferrocarril del norte ${ }^{16}$. La dirección recayó en

196-199. (Algeciras, Barcelona, Cádiz, La Coruña, León, Málaga, Madrid, Pamplona, San Sebastián Vitoria.). RUIZ GARCÍA, P.: "Imaz y Delicado, Fábrica de papeles pintados", Boletín de la Sociedad de Amigos de la Cultura de Vélez-Málaga, 5, 2006, pp. 59-64.

12 MADOZ, P.: Diccionario geográfico estadístico histórico de España y sus posesiones de ultramar, Madrid, 1845-1850, Edición facsímil de Juntas Generales de Álava, Vitoria, 1989, pp. 209-210. CAVEDA NAVA, J.: Memoria presentada al Excmo. señor Ministro de Comercio, Instrucción y Obras Públicas por la Junta calificadora de los productos de la industria española reunidos en la exposición pública de 1850, Madrid, Establecimiento Tipográfico de D. Santiago Saunaque, 1851, pp. 412-413. SAGARNA, I. M.a. MAÑUECO FRANCOS, A. Vitoria en 1850 año de la fundación de la caja de ahorros de la ciudad Vitoria Obra Álava, historia, obras, documentos, Vol. II El siglo XIX (1801-1850), Vit 1995, pp. 161-163. CANALS I AROMÍ M. . T.: Els papers pintats... op. cit., p. 28. Archivo Municipal de Vitoria-Gasteiz (en adelante AMVG) 35/014/008, 1848, s.f.

13 SAGARNA, I. M.a; MAÑUECO FRANCOS, A.: op. cit., pp. 86-87. SANTOYO, J. C.: op. cit., p. 163

14 SAGARNA, I. M.a; MAÑUECO FRANCOS, A.: op. cit., p. 76.

15 Archivo Histórico Provincial de Álava (en adelante AHPA) Antonio Cerain, 13505, 1852, fols. 230-231. El 11 de junio de 1852 Manuel Ordozgoiti vendía una acción de la sociedad de papel pintado y satinado a Abdon de Álava. El valor de la misma era de 26101 reales y fue vendida por 25500 reales.

16 Entre la abundante documentación generada por José María Villaoz destacamos: AHPA., Cipriano García de Andoin, 13591, 1847, fols. 44-45. Reclamación de una letra impagada: Ibid., Antonio Cerain, 13505, 1852, fol. 338. Ibid., 13506, 1853, fol. 349. Ibid., 13507, 1854, fols. 67-68. 446-447. Villaoz er miembro de la junta directiva de la sociedad minera Unión Alavesa a la que prestaba 20000 r.: Ibid. 


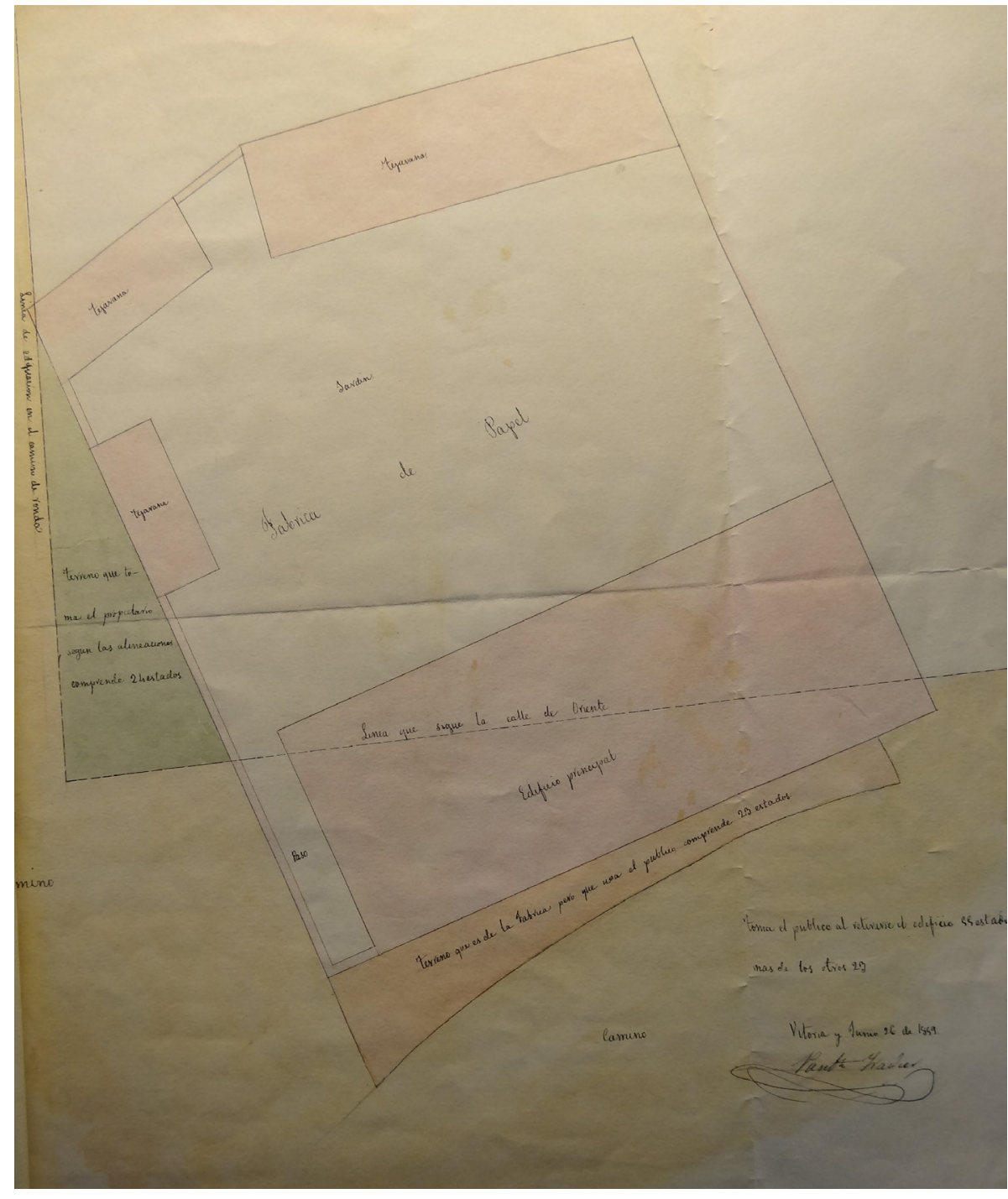

Fig. 1: Traza original de la fábrica Santa Isabel con respecto a la calle Oriente. AMVG-37-11-011
Manuel Ordozgoiti un conocido arquitecto que había obtenido su título en 1831 de la Junta Ordinaria de la Real Academia de San Fernando de Madrid, tras aprobar las distintas pruebas que exigía el examen ${ }^{17}$. Había participado en importantes proyectos como el del cementerio de Santa Isabel de Vitoria (1851), los planos de la nueva sede episcopal, Junto a Martín de Saracibar (1851) o la construcción de la capilla del Cristo "del Portalejo", en otras muchas obras ${ }^{18}$. Se advierte que además de ser arquitecto y ejercer como tal, participó en otros proyectos empresariales.

Saturnino de Ormilugue fue otro de los miembros implicados en la puesta en marcha de la fábrica de papel pintado de Vitoria. Participó de forma activa ejerciendo los puestos de encargado, administrador y finalmente director, convirtiéndose en el alma mater de la

13510, 1857, fols. 223-224. Testamento de la esposa de Villaoz, Gregoria Múgica: Ibid., fols. 579-580 Villaoz arrienda una casa en la Plaza Nueva, a la sociedad Casino de Vitoria: Ibid., 13511, 1858, fols. 612-612v. Villaoz anticipa distintas sumas a Pradines hermanos contratistas de la obras del camino de hierro en el trayecto por Villarreal de Zúmarraga: Ibid., 13513, 1860 fols. 124-125 y 126-127. Los señores Padrines hermanos se obligan a solventar la cantidad de 166.000 r. a Villaoz: Ibid., 13512, 1859, fols 522-522v. y 530-531. Convenio para anticipar 150.000 r. y declaración de tener anticipados otros 30.000 a Prospero Contant, francés, contratista del ferrocarril del norte: Ibid., fols. 608-609, 610-610v. Poder para pedir retención y litigar contra la sociedad del ferrocarril del norte. Al haber cesado los trabajos solicita el retention y lis contra la socied fols 846-847. Poder para percibir y retener caste 1862, fol. 73. Obligación para formar sociedad mercantil de Villaoz, Martín Oquendo y Andrés Pérez Ibid., 13516, 1863, fols. 141, 450. Protesto de letra de Villaoz: Ibid., 13512, 1859, fols. 246-248. 13515, 1862, fols. 336, 431, 997, 1023, 1042, 1044. Ibid., 13516, 1863, fols. 1, 33, 35, 47, 61, 63, 73, 95, 99, 147 , $149,159,153$.

17 LABORDA YNEVA, J.: El proyecto de arquitectura en la Real Academia de San Fernando: Las pruebas de examen de los aspirantes vascos, 1776-1855, Vitoria-Gasteiz, Servicio Central de Publicaciones del Gobierno Vasco, 2011, pp. 358-359. PALIZA MONDUATE, M. "Marcos Ordozgoiti, una figura polémica de la escultura vasca del siglo XIX", Revisión del arte Neoclásico y Romantico, Ondare, 21, Donostia, 2002, p. 417.

18 LARUMBE MARTIN, M.: "Tres proyectos neoclásicos para el cementerio de Vitoria", Kultura, n. ${ }^{0} 3$ 1991, pp. 36-39. EXTRAMIANA GONZÁLEZ, M.: El Cementerio De Santa Isabel De Vitoria-Gasteiz. Proyecto de Fin de Carrera dirigido por Ana de Begoña y Azcárraga (inédito), 2003. MIÑÓN SOTO, I.: La génesis de un espacio para la muerte en el siglo XIX vitoriano, la ciudad del sueño. Trabajo Fin de Grado dirigido por Jesús María González de Zárate, curso 2016-2017. pp. 25-28. https://addi ehues/ bitstream/halle/10810/23608/TFG Mi\%C3\%B1\%C3\%B3n.plf?sequence=2 DEL VAL V: Calles Vi-

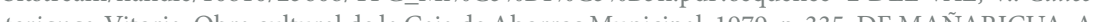
torianas, Vitora, Obracultural de la Caja de Ahor Obispados en Alava, Guipuzcoa y Vizcaya hasta la erección de la Diocesis de Vitoria (28 de abril de 1862, Vitoria, Editorial Eset Seminario Diocesano, 1964, pp. 362-363. VIDAL-ABARCA, J.: "Linajes alaveses, los Escoriaza", Boletín Sancho el sabio, año XXI, Tomo XXI, 1977, p. 316 


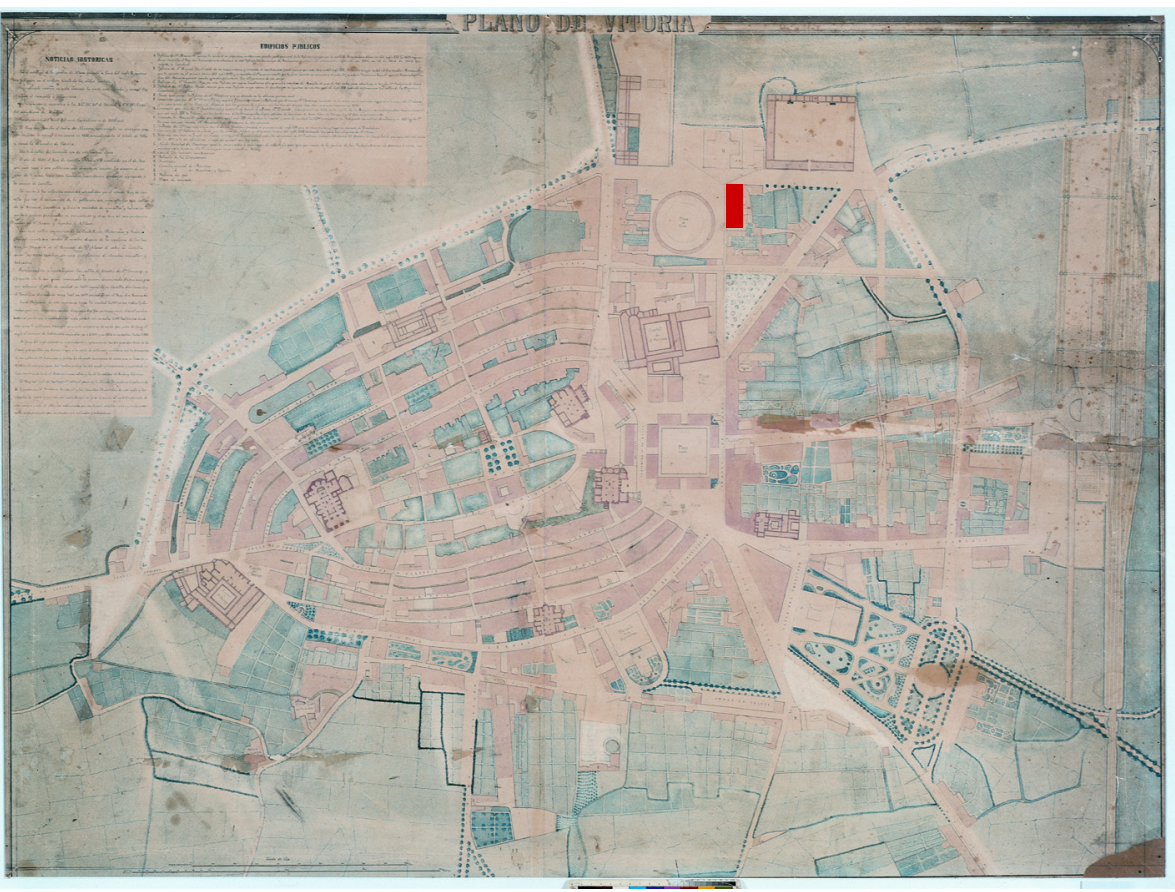

Fig. 2: Situación aproximada de la fábrica Santa Isabel a partir de 1860. Plano de Vitoria (c. 1858-1864) AMVG-AG-M-3. misma. Procedía de una conocida estirpe de libreros, encuadernadores e impresores de naipes originaria de Francia y asentada en el País Vasco desde mediados del siglo XVIII ${ }^{19}$ Tras la muerte de su padre en 1829, Saturnino de Ormilugue se hizo cargo de la fábrica familiar heredando "todos los moldes, utensilios y toda clase de herramientas de la fábrica de naipes y oficio de encuadernador..." para que pudiera seguir ejerciendo la profesión ${ }^{20}$. Se dedicó a la impresión de libros, publicaciones periódicas, naipes y otros artículos que vendía en la librería Ormilugue. Sus conocimientos sobre técnicas de impresión y uso de papel y sus contactos con Francia le hacían imprescindible en la administración de la fábrica de papel pintado Santa Isabel en la que participó activamente. No obstante, supo compatibilizar sus labores empresariales con cargos de gestión en el ayuntamiento como diputado, concejal o teniente alcalde, entre otros. Además también participó en otros proyectos empresariales como la construcción de la primera plaza de toros permanente de Vitoria ${ }^{21}$. Este coso fue inaugurado en 1851 y explotado por una sociedad de la que formaba parte Saturnino de Ormilugue ${ }^{22}$. Su amplia labor empresarial llegaba a su fin en 1870, con 63 años, al ser sorprendido por una pulmonía que truncó su vida. Por esas fechas ya solo quedaba viva su hija Marcelina, única heredera de todos sus bienes ${ }^{23}$.

En 1846 comienza la andadura de la fábrica de papel pintado Santa Isabel y se inician los primeros problemas con las instituciones municipales de Vitoria. El encargado de esta empresa, Saturnino de Ormilugue dirige una instancia al ayuntamiento solicitando que no se cobren impuestos sobre la materia prima empleada por dicha industria. Consideran que el papel no es un objeto de consumo para la población y que por ese motivo no se debería depositar en la alhóndiga, ni exigir arbitrios, puesto que suponía un entorpecimiento para el desarrollo de esta nueva empresa ${ }^{24}$. Seis días después los regidores contestan de la

19 SANTOYO, J. C. op. cit, pp. 153-164. Detalla toda la genealogía de esta familia desde 1792 hasta 1870. 20 SANTOYO J. C.: op. cit., p. 159

21 SAGARNA, I. M.a; MAÑUECO FRANCOS, A.: op. cit., pp. 85-87. SANTOYO, J. C.: op. cit., p. 163. La propuesta hecha al ayuntamiento corrió a cargo de Saturnino de Ormilugue, Tomás Tournán, José de Arana, Martín de Saracibar, Formerio Martínez de Leiva.

22 SANTOYO, J. C.: op. cit., p. 163. Los dueños de la plaza de toros fueron Silvestre Larrea, Clemente Olave y Saturnino de Ormilugue. AHPA., Antonio Cerain, 13509, 1856, fol. 523. Saturnino Ormilugue alquilaba la plaza a Juan Galíndez. Ibid., 13511, 1858, fols. 186-187. Fue alquilada a Esteban Ezquerecoch.

23 Ibid, pp. 160-164. Saturnino de Ormilugue estuvo casado dos veces y tuvo dos hijos con su primera

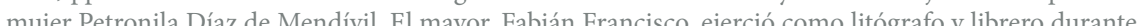
algunos años hasta que su carrera quedó truncada con 26 años, y la menor Marcelina Josefa estuvo casada con Antonio Masson.

24 AMVG., 35/012/014 (20 de mayo de 1846). 


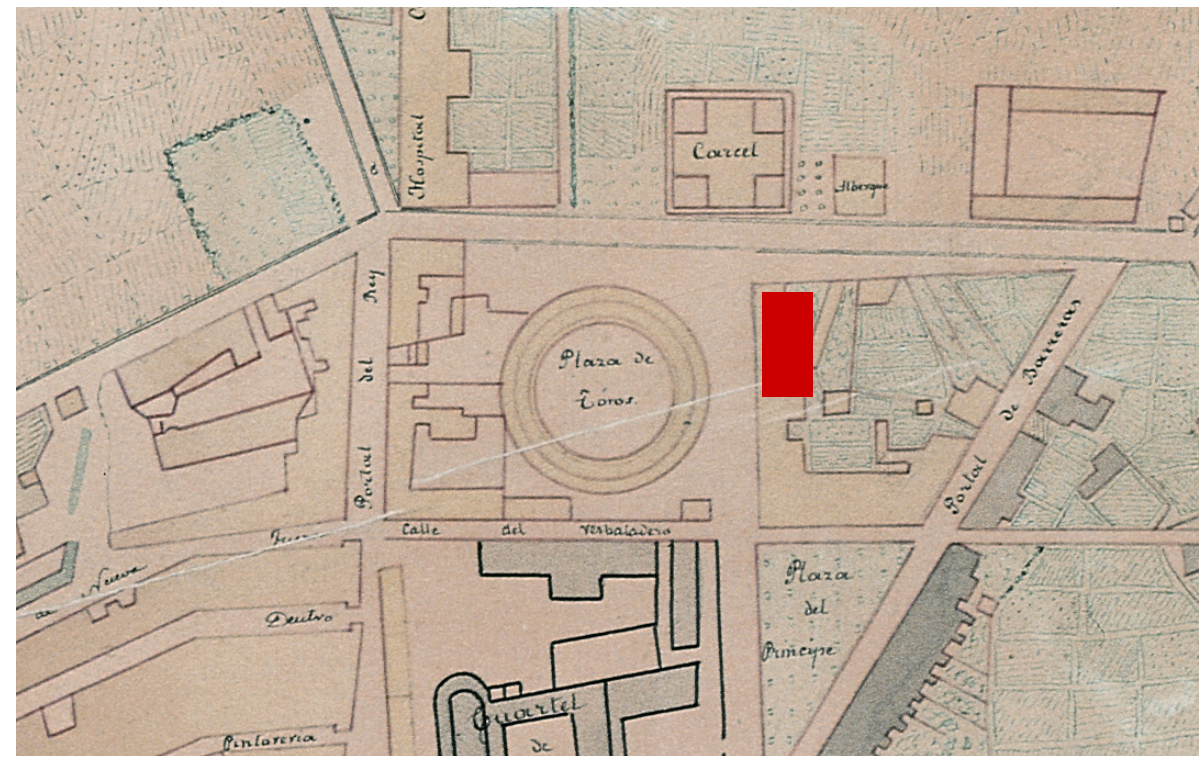

Fig. 3: Detalle del Plano de Vitoria (1865) atribuido Francisco de Paula Hueto. AMVG-AG-M-2. siguiente manera, "si bien encuentran muy razonable el que se de a las fabricas de cualquier clase de industria que se establezcan en esta ciudad toda la protección posible, entiende sin embargo que siempre deberá ser sin prejuicio de los arbitrios con que cuenta para cubrir sus muchas y perentorias obligaciones" 25 . La respuesta no fue suficientemente convincente para la sociedad de papeles pintados que consideraba que las autoridades político administrativas no estaban apoyando lo suficiente a esta "industria naciente", teniendo en cuenta que daba sustento a muchas familias y reportaba muchos beneficios al país ${ }^{26}$. La comisión de hacienda ratificaba su primera sentencia pues a pesar de dar "todo su apoyo a la industria y a las artes como fuente principal de riqueza y prosperidad de las naciones" no podía crear diferencias entre distintas empresas, pues en esta misma situación estaban otras muchas más antiguas, y si dejaban de cobrar aranceles a una, vendrían "las demás haciendo igual reclamación" 27 .

Realmente este problema venía de atrás, pues en 1844 un grupo de impresores y otros profesionales que utilizaban papel, defendían sus intereses ante el ayuntamiento por el aumento de los impuestos en dicho material y porque se descargaba en la alhóndiga como cualquier otro producto ${ }^{28}$. Esto último generaba muchos problemas puesto que

"la clase de personas, por lo regular no muy aseadas, sin cuidados que se emplean para el descargue en la alhóndiga, la mezcla de articulos liquidos y solidos que alli tambien se depositan y que comúnmente impregnan y prestan manchas sobre los puntos por dond

25 AMVG., 35/012/014 (26 de mayo de 1846). Se concreta que se debe pagar 15 r. por la carga de pape blanco, $6 \mathrm{r}$. en el de entrega del reino y 65 maravedíes por peso.

26 ANGULO MORALES, A.: "Entre la promoción y la protección: el banco de emisión y descuento de Vitoria (1863)", en REGUERA, I.; PORRES, R., (eds.): Poder, pensamiento y cultura en el Antiguo Régimen, Actas de la 1. a semana de estudios históricos "Noble villa de Portugalete", Donostia, Eusko Ikaskuntza, 2002, 229. AMVG.,35/012/014 (21 de octubre de 1846).

27 AMVG. 35/012/014 (24 de octubre de 1846).

28 AMVG., 02/0326/002 (23 de octubre de 1844). La demanda la firmaban Saturnino de Ormilugue, Saturnino Ylones, Santiago de Arroyabe, Egaña y compañía, Miguel de Uralde y José de Larasqueta. Se adjuntaban dos Reales Cédulas relativas a la impresión de papel y su importación: Real Cedula de S.M y señores de su real y supremo consejo por la cual se manda cumplir y observar la ley y auto acordado y tratan de lo que se ha de observar por los prelados eclesiásticos en cuanto a dar licencias para la impresión de papeles o libros de los que express la mismo ley y auto acordado en la forma que se contiene. Madrid, imprent introducción en estos reinos de todos los libros encuadernados fuera de ellos a excepción de los que vengan en papel o a la rustica y de las encuadernaciones antiguas de manuscritos y de libros impresos y se conceden seis meses para la introducción de los que ya estén pedidos. Madrid, imprenta de Pedro Marín, 1778 
pasan y en que permanecen, nos causan las mas veces perjuicios considerables en el papel, de modo que mucha parte de sus resmas llegan feamente emporquecidas a nuestros almacenes y las damos con desprecio o las tenemos que despachar por que el consumidor busca lo bueno, como es justo, y desecha el género con averias" ${ }^{29}$.

El ayuntamiento tomaba en consideración lo expuesto por estos profesionales y ordenaba calcular el arancel cuando el papel llegara a la alhóndiga sin necesidad de descargarlo, y así una vez abonado pudiera ser llevado de forma directa a sus dueños. Además se mantenía el impuesto sin subida alguna hasta final de año ${ }^{30}$.

El 16 de diciembre de 1846 el impresor y litógrafo Ignacio Egaña lideraba una nueva reclamación a la administración local ${ }^{31}$. En primer lugar, solicitaba que el papel que llegara con carta de porte no pasara por la alhóndiga y fuera directamente a las fábricas. También exigía que los derechos del papel no se pagaran solo por cargas y medias cargas ( 12 arrobas) y se pudiera hacer proporcionadamente al peso. A todas estas demandas añadía que se rebajara el impuesto establecido sobre este producto ${ }^{32}$. Seis días después el ayuntamiento consideraba estas peticiones totalmente inadmisibles, porque el papel era un artículo cuyo arancel requería su paso por la alhóndiga para su reconocimiento y evitar fraudes. Además se consideraba que el cobro de derechos por cargas y medias cargas era más sencillo y útil para los recaudadores y que teniendo en cuenta las muchas necesidades de la ciudad, no se podían rebajar los aranceles ${ }^{33}$.

Los fundadores de la fábrica de papel pintado Santa Isabel no cejan en sus reclamaciones proteccionistas y el 7 de diciembre de 1847 exponían a la municipalidad la utilidad de este establecimiento para la ciudad ${ }^{34}$. Solicitaban la "mano protectora" evitando

29 AMVG., 02/0326/002 (23 de octubre de 1844)

30 AMVG., 02/0326/002 (30 y 31 de octubre de 1844).

31 SANTOYO, J. C.: op. cit., pp. 193-236. La imprenta Egaña estuvo presente en Vitoria buena parte de siglo XIX, primero como Egaña y Compañía (1839-1846), después como Ignacio Egaña (1846-1868 y finalmente como Viuda de Egaña e Hijos (1868-1877) y Viuda de Egaña e Hijo (1878-1881). Ignacio Egaña fue un importante impresor, litógrafo, encuadernador y comerciante de libros, además de publicar un gran número de textos descubrió en 1841 una cantera de piedra litográfica en Oquina (Gipuzkoa) que se consideró mejor "que las de Múnich" o al menos de la misma calidad.

32 AMVG 35/012/070 (16 de diciembre de 1846).

32 Ibid., (22 de diciembre de 1846).

34 ROSE-DE VIEJO, I.: op. cit., pp. 91-92. Esta reclamación de protección por parte del estado también es una reclamación por Pedro Giroud de Villette, director de la Real Fábrica, para que no se pudieran "entorpecimientos que detendrian su marcha despues de largos sacrificios", pues esta fabrica se había montado a imagen y semejanza de las existentes en Francia para lo que habían necesitado adquirir los conocimientos necesarios de ese país ${ }^{35}$. Consideraban preciso proteger la "industria naciente" teniendo en cuenta la "inmensa utilidad que reporta la fábrica a la ciudad, haciendo que se empleen brazos del pais e instruidos que puedan dar vida y vigor a nuestra decaida industria"36. Se ponía de manifiesto al consistorio que el papel blanco y ordinario que empleaban como materia prima, debía pasar por un costoso proceso de elaboración hasta ser pintado y poder consumirse. Además todo este trabajo lo realizaban muchos operarios "extranjeros y naturales" que a su vez también contribuían con los impuestos de la ciudad. El administrador, Saturnino de Ormilugue presentaba cuatro muestras del referido papel, "cuatro rollos de a 10 varas cada uno, dos blancos y dos de color" con el sello de la fábrica. Por lo expuesto pedían que a esta materia prima "ordinaria" no se cobrara el mismo impuesto que al papel fino para escribir, que no precisaba de ninguna preparación ni gasto. También se exigía no pagar derechos por el papel pintado de esta fábrica que se vendía a otros puertos ${ }^{37}$.

Pero no quedaron ahí las dificultades a las que tuvo que enfrentarse esta joven industria artística. El 19 de mayo de 1857 los vecinos cercanos a esta fábrica interponían una reclamación al ayuntamiento por los vapores insalubres que salían de ella y las aguas tintadas que se filtraban a los pozos con los que se regaban las huertas cercanas, lo que estaba provocando que las plantas quedaran dañadas. Se pedían medidas sanitarias al consistorio por miedo a que la población se viera afectada por un nuevo brote de cólera ${ }^{38}$. Esta preocupación era comprensible ya que en el año 1856 Vitoria había vivido una epidemia de esta mortífera enfermedad, muy presente en la España del siglo XIX ${ }^{39}$. Para

importar papeles "que vengan de reinos extraños" pues quería "convertir su fábrica en un estanco, en un verdadero monopolio". También solicitaba al rey en 1818 que no se abrieran los fardos de papel o toneles de primeras materias en la aduana de Vitoria y se mandaran de forma directa a la Real fábrica. La petición proteccionista de Giroud quedó denegada en 1819.

35 AMVG., 35/014/008 (7 de diciembre de 1847).

36 Ibid.

37 Ibid. (11 de enero de 1848).

38 AMVG., 37/024/101 (19 de mayo de 1857).

39 VELASCO LÓPEZ, E. Crónicas y biografías alavesas, Vitoria, Imprenta Provincial, 1910, pp. 98, 100127. Durante el año 1854 se hicieron rogativas y se tomaron medidas higiénicas para superar la enfermedad. En enero de 1856 se cantó un Te Deum en agradecimiento a su extinción. SERDÁN Y AGUIRREGAVIDIA, E.: Vitoria, el libro de la ciudad, Vitoria, 1927, (ed. Vitoria, 1985, Tradiciones alavesas, tomo X, parte III), pp. 248-249. 
comprobar la reclamación interpuesta por los vecinos, cuatro días después los médicos y cirujanos de la ciudad pasaban por los distintos departamentos de la fábrica, examinando los materiales empleados en ella y dictaminando que no parecía, a primera vista, nocivo para la salud pública. La pestilencia que molestaba a los residentes de las inmediaciones procedía de la cocción de pieles y restos de animales para la fabricación de cola ${ }^{40}$. Esta labor se hacía en una habitación cerrada sin comunicación con el exterior ni con otras secciones de la fábrica, por lo que las únicas personas expuestas a los hedores emitidos eran los operarios que realizaban esta labor. Rara vez podía el mal olor llegar a las casas cercanas y menos infectar la atmosfera de modo permanente. Las aguas con restos de colorante en disolución o suspensión que afectaban a los pozos de regadío cercanos no parecían ser demasiado perjudiciales para la vegetación. La comisión encargada de la salubridad pública se había entrevistado con el hortelano más próximo a la fábrica, para comprobar que no se advertía ninguna alteración en los vegetales cultivados y regados con esas aguas. Se concluye que a simple vista no eran perjudiciales para la salud, siempre que no fueran consumidas para beber, "por muy saturadas que estuvieran de los residuos del tinte". No obstante, con la intención de ofrecer datos más precisos se proponía que fueran analizados por los "peritos químicos"

El 6 de noviembre de 1857 los vecinos cercanos a ésta fábrica volvían a interponer una queja ante el ayuntamiento, por la falta de información sobre las pesquisas que habían sido llevadas a cabo y por los mismos motivos esgrimidos meses atrás. Se insistía en el olor fétido que afectaba a todo el barrio y en las aguas mezcladas con colorantes y sustancias venenosas que, en esta ocasión, habían provocado la muerte de nueve patos ${ }^{42}$. Desde el consistorio se encargaba al veterinario que reconociera los animales y si fuera necesario les hiciera una autopsia. Se plantean como posibles causas del fallecimiento de estas aves, las aguas contaminadas con tintes y otros productos químicos desechados por la fábrica de papel pintado, y por el taller de coches de Tomás Lafuente. Para averiguar la verdadera

40 La cola se empleaba para distintos usos pero sobre todo como ligante para el color, las de procedenci animal en la correcta proporción permitían imprimir sin que el color se craquelara al secar. Fueron desplazadas por las de origen vegetal, como las de fécula o almidón. También resultaban necesarias para que la capa pictórica no se desprendiera del soporte. "Vid." HARTMUT, G.: "Fabrication des papiers peints, des couleurs d 'impression et de couchage à l' aide de colorants organiques et de pigments" Bayer Faber des couleur d "

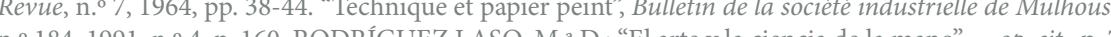
n. ${ }^{\circ} 184,1991$, n. ${ }^{\circ} 4$, p. 160. RODRÍGUEZ LASO, M. ${ }^{a}$ D.: "El arte y la ciencia de la mano"..., op. cit., p. 7. 41 AMVG., 37/024/101 (23 de mayo de 1857).

42 Ibid., (6 de noviembre de 1857) causa de estas defunciones, se solicitaba someter a un análisis químico las aguas y los estómagos de los patos en la casa del subdelegado de farmacia de la ciudad. Como medida higiénica previa se mandaba evitar que, de ahí en adelante, los animales hicieran uso de ellas ${ }^{43}$.

A pesar de estas dificultades la fábrica de papel pintado Santa Isabel siguió su andadura produciendo gran variedad de productos decorativos y artísticos para el mercado local y nacional, hasta 1860, año en el que tiene un pequeño parón por motivos ajenos a ella. En 1859 el ayuntamiento decide embellecer la calle Oriente (actual Postas) ${ }^{44}$, en cuya cercanía se encontraban la fábrica de papel pintado. Adyacente estaba la primera plaza de toros permanente de la ciudad y la nueva cárcel que en 1858 había iniciado su construcción el arquitecto Martín de Saracibar, cuya fachada se abría a la calle Paz en su encuentro con la de Oriente ${ }^{45}$ (Figs. 1-2-3). La intervención urbanística era importante pues la nueva calle debía transitar por una zona sinuosa con casas de labradores y huertas tapiadas para convertirse en una vía residencial con nuevas edificaciones ${ }^{46}$. Uno de los problemas que los técnicos municipales encontraron fue que el edificio central de la fábrica coincidía con la línea principal de la calle Oriente (Fig. 1). Esto suponía que había que derribar este establecimiento y volverlo a construir, desplazándolo unos metros para quedar situado definitivamente al final de la calle Oriente, actual Postas, haciendo esquina con la calle Paz (Fig. 2). El plano lo realizaba el 16 de junio de 1859 el arquitecto Pantaleón Iradier encargado de otras muchas reformas urbanísticas en Vitoria ${ }^{47}$. En él se puede ver con claridad la posición de la fábrica respecto al nuevo trazado y como estaba compuesta por un edificio principal de forma rectangular de dos pisos y tres más pequeños cubiertos por tejavana alrededor de un amplio jardín (Fig. 1).

3 Ibid., (7 de noviembre de 1857).

44 AMVG., 37/11/011 (8 de junio de 1859).

45 VELASCO LÓPEZ, E.: op. cit., pp. 101-102. SERDAN Y AGUIRREGAVIDIA, E.: op. cit., pp. 266-267, 279. BECERRO DE BENGOA, R. op. cit. p. 182. CENICACELAYA, I. SALONA, I (et al): Arqui-

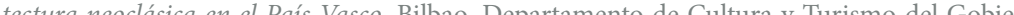

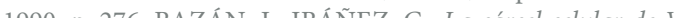
Vitoria-Gasteiz, 2000 .

46 SERDÁN Y AGUIRREGAVIDIA, E.: op. cit., p. 279.

47 AMVG., 37/11/011 (26 de junio de 1859). 


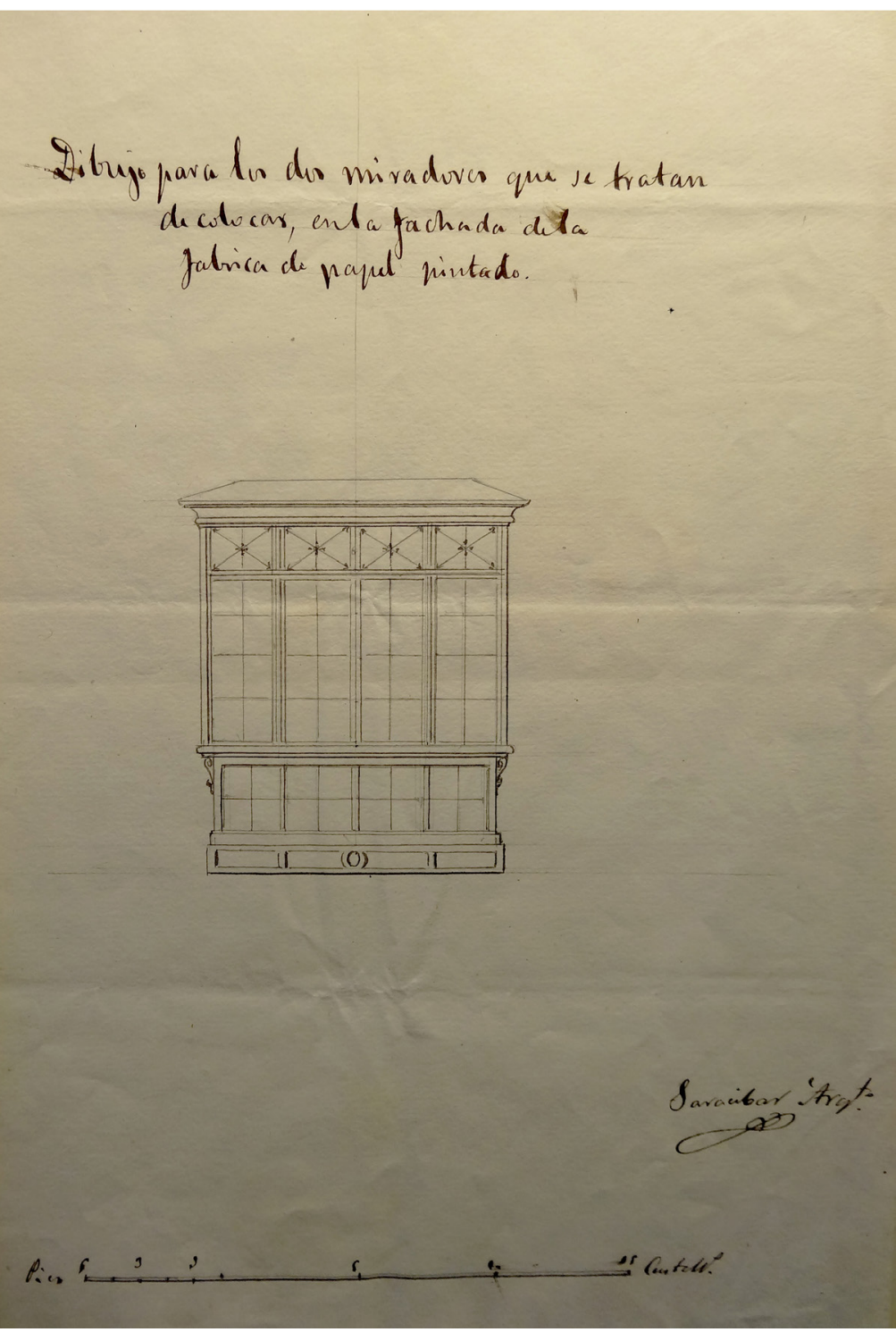

Fig. 4: Traza original de los miradores propuestos para la fábrica de Santa Isabel. AMVG.37.11.011
Acometer este nuevo proyecto de renovación urbanística suponía un importante desembolso para el consistorio, ya que había que indemnizar a los propietarios de la fábrica por el derribo y el terreno que iba a pasar a la municipalidad. Para que no existieran desagradables sorpresas se presentaron estimaciones de lo que supondrían dichas compensaciones. Se barajaba un gasto aproximado de unos 50000 reales que podían llegar a reducirse significativamente. Unos 38000 reales el derribo y la nueva construcción, que podía llegar a reducirse a 36000 reales. Los 54 estados de terreno que pasaban a manos públicas alcanzaban los 4500 reales, por lo que la indemnización que podían recibir los propietarios de la fábrica sería de 39500 o 40500 reales. Finalmente en marzo de 1860 se llegó a un acuerdo con el administrador de la fábrica, Saturnino de Ormilugue, por el cual el ayuntamiento le debía de satisfacer a modo de indemnización 40000 reales $^{48}$. Se concretaba en el acuerdo que el señor Ormilugue debía levantar la nueva construcción en la línea que le marcara el arquitecto. Que la fachada principal debía colocarse frente a la cárcel, abierta a la actual calle Paz y que la parte urbanística relativa a las aceras corrían a cuenta del consistorio ${ }^{49}$. En abril del mismo año se presentaba el plano de la fábrica para que fuera aprobado por el ayuntamiento con las dos fachadas vistas, la que daba a la calle Oriente (actual Postas) y la principal que se abría a la actual Paz, frente a la cárcel (Fig. 4). Se solicitaba también que el arquitecto municipal demarcara la línea en la que se debía levantar el nuevo edificio ${ }^{50}$. Anteriormente se había enviado al consistorio un diseño de dos miradores volados que se querían colocar en la fachada de la fábrica, diseñados por el arquitecto Martín de Saracibar, para que fueran aprobados (Fig. 4). Este permiso era absolutamente necesario pues en el artículo 86 del Bando de policía se concretaba que, "se prohíbe en la parte nueva de la ciudad abrir balcones, ventanas y puertas, colocar miradores, ni modificar las fachadas y buhardillas sin autorización del ayuntamiento el cual nunca podrá concederlas si los edificios están fuera de la línea”. El consistorio denegó el permiso hasta que el edificio no estuviera dentro de la línea del nuevo trazado (Fig. 5).

8 AMVG., 37/11/011 (18 y 20 de marzo de 1860). SERDÁN Y AGUIRREGAVIDIA, E.: op. cit., p. 279

49 AMVG., 37/11/011 (18 y 20 de marzo de 1860).

50 AMVG., 35/02/081 (25 de abril de 1860).

51 AMVG., 37/11/011 (8, 27, 29 de febrero de 1860). AHPA., Antonio Cerain, 13514, 1861, fols. 871-871v. En esta vorágine urbanística Saturnino de Ormilugue y José María Villaoz aprovecharon para invertir en algunas propiedades de la zona. En concreto el día 10 de octubre de 1861 compraban un terreno con su huerta junto a la plaza de toros y a la nueva carretera de Pamplona, por 10000 reales. Finalmente Ormilugue se quedó con el terreno, en el número 8 de la calle Oriente, donde se construyó una casa con cuatro habitaciones, taller, leñera y huerta. Ibid., fols. 874-874v. Saturnino Ormilugue "al retirar la fábrica de papel pintado y construir la casa en la calle Oriente" cedió a los señores Pedro de Bengoa y Juan de Unzalu 3875 pies de terreno a la parte de oriente de dicha casa y para levantar otra. 


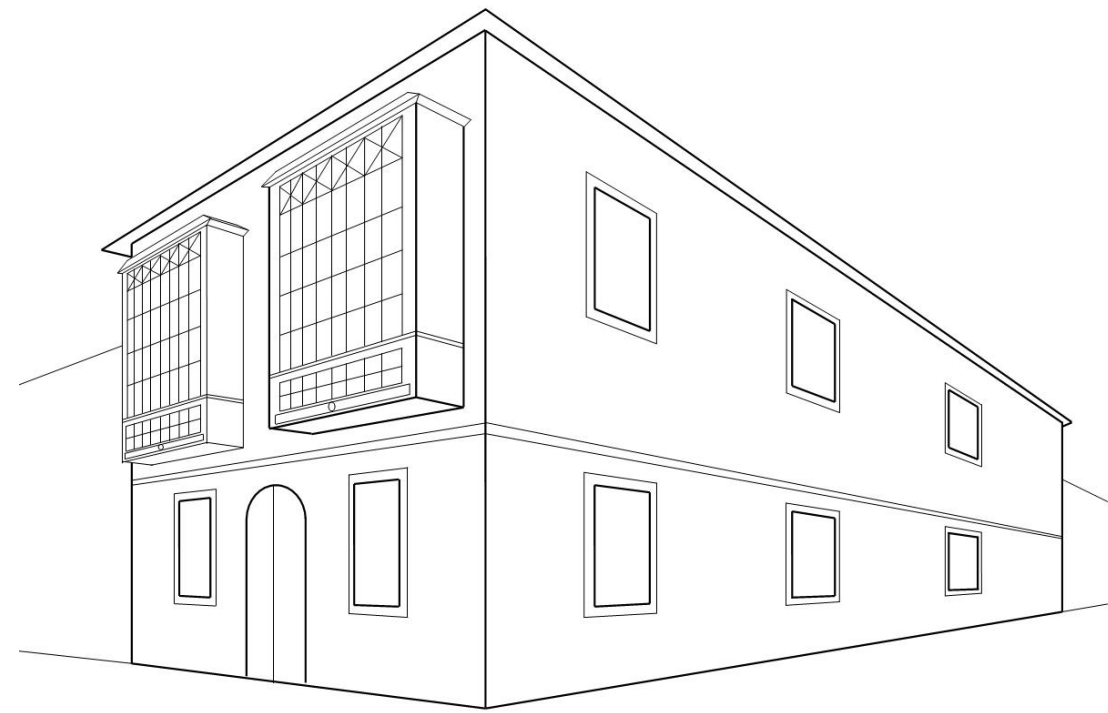

Fig. 5: Reconstrucción hipotética de la fábrica de Santa Isabel (dibujo Brayan Chipana)

\section{DIFICULTADES EN EL PROCESO DE INDUSTRIALIZACIÓN EN ÁLAVA}

El proceso de industrialización en Álava fue algo más lento que el de Bizkaia o Gipuzkoa iniciado en 1841 con el traslado de las aduanas a la costa y a la frontera francesa ${ }^{52}$. Álava permaneció unida a la tradición artesanal del pequeño taller sin mecanizar aunque, sí que es cierto, que contó con algunas experiencias novedosas como la fábrica de papeles pintados de Santa Isabel, la de espejos y marcos dorados de Juan Leonardo Zabala, establecida en 1845 o la de carruajes de Justo Montoya desde 1840 , todas ellas en Vitoria ${ }^{53}$. Por las mismas fechas y fuera de la capital alavesa hubo otras experiencias interesantes como la cría de

52 FERNANDEZ DE PINEDO, E: "De la primera industrialización a la reconversión industrial: la economía Vasca entre 1841y 1990" en GERMAN, L: LLOPIS, E.; MALUQUER, J.; ZAPATA, S., (eds.): Historia de la economía regional de España, siglos XIX-XX, Barcelona, Crítica, 2001. AJA, G., (et al.): Patrimonio industrial vasco, I-II, Vitoria-Gasteiz, Servicio Central de Publicaciones del Gobierno Vasco, 2012, p. 23 53 DE PABLO, S.; DE LA GRANJA, J.L.; RUBIO POBES, C.: Breve historia de Euskadi, de los fueros a la gusanos de seda en Laguardia, una fábrica de hierro colado en Araia, otra similar que producía puntas de París en Arriaga, una manufactura de harinas en Salvatierra y otra de aceite y chocolate en Laguardia ${ }^{54}$

Todas estas experiencias no fueron suficientes para que Álava se equiparara al proceso industrial que estaban sufriendo las provincias costeras. La intervención de las instituciones alavesas se dirigió, en opinión del profesor Angulo Morales, hacia dos direcciones, la intervención directa de la hacienda foral en el control productivo y fiscalizador de la economía naciente y por otro lado, en el fomento de empresas privadas. Los proyectos de ámbito industrial, financiero o comercial corrieron a cargo de capital privado y solo contaron con el apoyo posterior de las instituciones ${ }^{55}$

En el ámbito intelectual y de análisis periodístico hubo una manifiesta preocupación por el desarrollo de la industria en el territorio alavés. Eruditos como Ramón Ortiz de Zárate, director de El Lirio, periódico científico, literario e industrial, publicaron buen número de artículos dedicados a la industria alavesa y a las causas que impedían su desarrollo tanto en Álava como en el resto de España. Entre los problemas más acuciantes planteaba, la falta de protección por parte de las instituciones ${ }^{56}$, la poca instrucción y conocimientos teóricos ${ }^{57}$,

autonomía, Barcelona, Debate, 2011. MADOZ, P. op, cit, pp. 209-210. Madoz considera que el mayor problema que tiene Álava para la industrialización es la falta de carbón de piedra y saltos de agua que no permite instalar máquinas hidráulicas ni de vapor verdaderos motores de la industrialización.

54 El Lirio. Periódico científico, literario e industrial, tomo $1 .^{\circ}$, n..$^{\circ} 4$ (22 de noviembre de 1845), pp. 29-30. Ibid., tomo $2 .^{\circ}$, n. ${ }^{\circ} 1$ (1 de mayo de 1846), p. 8. MADOZ, P.: op. cit., pp. 209-210. Madoz destaca la producción realizada por los artesanos de la madera con destacados muebles de nogal y de hierro con sus conocidas camas. "A esta perfección contribuye la Academia de dibujo que está concurrida de artesanos jóvenes" BECERRO DE BENGOA, R. El libro de Álava, Vitoria, Hijos de Manteli, 1877 pp. 197-198. aunque la provincia seguía siendo agrícola. Destaca fábricas de ebanistería, de coches, camas de hierro, confiterías, curtidos, fósforos, bujías, jabones, latonería, bombas, fundiciones de hierro, lozas ordinarias, lanas, colas, armas de fuego, carbón animal (negro animal), cemento y cal. MADOZ, P.: op. cit., pp. 209-210. SAGARNA, I. M.a; MAÑUECO FRANCOS, A.: op. cit., pp. 75-77. En 1850 en Vitoria estaban establecidas fábricas de curtidos, mantas, carruajes, sombreros, baterías y utensilios de cocina, alfarera hules, marcos y espejos y camas de hierro, entre otras.

55 ANGULO MORALES, A.: op. cit., p. 229.

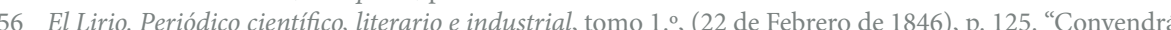
que el gobierno y las diputaciones provinciales faciliten a los pueblos al menos los mejores modelos que de herramientas y máquinas de todo género se conocen en el estrangero".

57 Ibid., tomo 1. ${ }^{\circ}$, (8 de febrero de 1846), p. 108. Ramón Ortiz de Zárate en artículo titulado Causas que impiden los adelantos de las mejoras materiales en España opina que "la falta de ilustración y conocimientos teó- 
el mal estado de las comunicaciones y el transporte o la inexistencia de espíritu asociativo entre otras muchas más carencias. Se advertía que los buenos artesanos de estas tierras trabajan solos,

"sin capitales y sin las máquinas y herramientas, que se inventan todos los días en el extranjero, y que tanto facilitan la perfección y el trabajo, y sin educación literaria, no pueden tomar el vuelo, que bien pronto tomarían si algunos ciudadanos benéficos se asociaran y difundieran entre ellos las nociones científicas propias de sus profesiones proporcionándoles herramientas, máquinas, talleres y modelos a imitar"58.

Otro de los grandes problemas que sufrían las provincias en opinión del ámbito intelectual era la pérdida de grandes capitales que dejaban sus tierras natales para marcharse e invertir en la capital. Esto se consideraba "una calamidad para los intereses generales, porque estos no pueden prosperar si los hombres de más saber y valía se encierran en la capital de la monarquía, dejando a las provincias en una orfandad lastimosa"59.

En este ambiente no demasiado propicio para el desarrollo industrial nació la fábrica de papel pintado de Santa Isabel de Vitoria. El propio administrador Saturnino de Ormilugue analizaba la situación productiva del país y consideraba que

"ésta provincia que hasta ahora ha sido puramente agricultora y que no ha tenido mas riqueza que la que le producia el cultivo de los campos y cria de ganados, esta llamada por la naturaleza y por las recomendables prendas y laboriosidad de sus habitantes a figurar entre las provincias fabriles e industriales de España". "El movimiento industrial y fabril que distingue a las sociedades modernas ha comenzado a dar los primeros frutos en Yberia y el espíritu de mejoras y adelantos positivos ha encontrado gran acogida en todas las partes despertando la afición a la maquinaria y a las artes, abandonadas hasta el presente a la especulación extranjera que ha sabido explotar este abandono importándonos sus artefactos y mercancías llevándonos en cambio inmensas cantidades en metálico. Afortunadamente va renaciendo poco a poco la industria española y si las autoridades la protegen pronto podrá no solo competir sino dar la ley y dominar a la extranjera en nuestros mercados" ${ }^{\prime 60}$.

ricos perjudica a nuestros intereses y que para vencer este inconveniente deben establecerse escuelas de agricultura y comercio y cátedras donde se expliquen las ciencias físico-matemáticas con aplicación a las artes". 58 Ibid., tomo $1 .^{\circ}$, n. ${ }^{\circ} 4$ (22 de noviembre de 1845), p. 29.

59 Ibid., (8 de febrero de 1846), pp. 108-109.

60 ATHA-FHPA-DH-786-1, (5 de mayo de 1847).
Todas estas opiniones ponen de manifiesto que las nuevas empresas reclamaban mayor apoyo institucional tanto del estado como del propio municipio. Se trataba de imponer políticas proteccionistas que incidieran en la bajada de la presión fiscal sobre la materia prima empleada y los productos elaborados, así como, en un control de las importaciones extranjeras con las que resultaba difícil competir. A todo esto había que añadir la idea generalizada de que cualquier manufactura venida de fuera era mejor que la que se producía en casa:

"Si en España se construye una fabrica y en ella se elabora cualquier artefacto, nadie se satisface con que este sea de mejor calidad y menos coste que los antiguos. Enseguida se le coge, se le compara con los más acreditados de Inglaterra o Francia y sino les excede en mérito y baratura se le desprecia y arrincona, olvidado que el fabricante frances o ingles ha llevado su industria a la perfección despues de muchos años de paciencia"61.

\section{LA FÁBRICA DE SANTA ISABEL. CARACTERÍSTICAS Y PRODUCCIÓN}

Después de analizar algunas de las dificultades que la fábrica de papel pintado de Santa Isabel tuvo a lo largo de su existencia, vamos a presentar aspectos como la organización producción, materiales empleados, precios y otras cuestiones relativas a este establecimiento industrial y artístico. La no existencia del archivo de la fábrica con los registros de cuentas o los libros de muestras no nos permiten ofrecer una visión precisa de la misma, ya que tenemos que partir de datos parciales ofrecidos por archivos, hemeroteca y bibliográficos.

La fábrica en su origen disponía, como se puede apreciar en el plano original, de un edificio principal rectangular de dos alturas "de 170 metros de largo y 32 de ancho". Además contaba con tres más pequeños cubiertos por tejavana, probablemente dedicados al almacenamiento de papel o la elaboración otros productos necesarios ${ }^{62}$ (Fig. 1). Disponía de un gran jardín circundado por estos edificios y de un pozo de agua cercano que abastecía a esta industria, algo absolutamente necesario para su producción y común a cualquier otro establecimiento de elaboración de papel pintado ${ }^{63}$. Junto a la fábrica había un pequeño riachuelo al que

61 Ibid., (22 de febrero de 1846), p. 125

62 AMVG., 37/11/011 (26 de junio de 1859). CAVEDA y NAVA, J.: op. cit., p. 412.

63 ROSE-DE VIEJO, I.: op. cit., p. 26, 195. Igualmente la Real Fábrica de Papeles Pintados de Madrid se encontraba situada en un lugar con abundante agua necesaria para su producción. 
iban a parar los restos de aguas residuales mezcladas con colorantes y otras sustancias, que como ya hemos comentado generaron bastante alarma en el vecindario cercano ${ }^{64}$ Los datos que tenemos sobre la organización son escasos, solo sabemos que disponía de diferentes departamentos. En el primer piso un gran salón para "satinar, ruletar y bruñir", otro con las mesas de estampado y otro con la máquina de imprimir. Además había una habitación estanca para la producción de colas y una sala de fabricación de colores dirigida por un químico, lo que facilitó que este establecimiento fuera "enteramente independiente del extranjero" ${ }^{65}$. En el segundo piso las salas de fondear o de fondos, la de impresión de los mordientes y dorados, un almacén con abundantes estanterías y un despacho. Alguna de estas habitaciones estaban empapeladas y otras pintadas, así como puertas y ventanas ${ }^{66}$.

La fábrica de Santa Isabel de Vitoria, al igual que otras similares en España, había sido montada siguiendo modelos franceses, lo que no resulta extraño teniendo en cuenta que éste país era puntero y tenía una larga tradición en la producción y diseño de papeles pintados $^{67}$. A esto hay que sumar la relación constante que las provincias vascas tuvieron siempre con Francia de la que venían importantes novedades industriales, artísticas y culturales. Este establecimiento disponía, en un inicio, de una plantilla compuesta por 40 o 50 operarios especializados, reducidos en 1850 a 25 más el administrador ${ }^{68}$. Algunos de ellos eran "extranjeros" y el resto "naturales" 69 aunque habían necesitado adquirir los conocimientos necesarios en Francia y estaban apoyados en su trabajo diario por los especialistas contratados de fuera ${ }^{70}$. Era habitual que estas fábricas tuvieran una plantilla compuesta por un químico y colorista, impresor, fondeador, encolador, cortador de papel,

64 AMVG., 37/024/101 (mayo, noviembre de 1857).

65 AMVG., 37/11/011 (18 de marzo de 1860). Ibid., 37/24/101 (23 de mayo de 1857). MADOZ, P.: op. cit., pp. 209-210. CAVEDA y NAVA, J.: op. cit., p. 412

66 Ibid. Esta organización de las salas era similar a la de otras fábricas como se puede ver en ROSE-DE VIEJO, I.: op. cit., pp. 114-116.

67 ROSE-DE VIEJO, I.: op. cit., pp. 49. La Real Fábrica de Papeles Pintados de Madrid (1786-1836) también se montó a imagen y semejanza de las existentes en Francia. LA HOUGUE, V.: op. cit., pp. 13-48.

68 MADOZ, P.: op. cit., pp. 209-210. CAVEDA y NAVA, J.: op. cit., p. 412. CANALS AROMÍ. M. T.: "prin cipales centros..., op. cit., p. 77, 78. La fábrica Vda. De Ribed e Hijo situada en Villava (Pamplona) empleaba 44 hombres y 54 mujeres.

69 AMVG, 35/014/008 (11 de enero de 1848) "que contribuyen también a los impuestos de esta ciudad". ROSE-DE VIEJO, I.: op. cit., pp. 49-51. La Real Fábrica de Papeles Pintados de Madrid (1786-1836) llegó a tener de 32 a 40 operarios de distintas nacionalidades, franceses, alemanes, suizos e italianos.

70 AMVG., 35/014/008 (7 de diciembre de 1847). ensamblador, pintor-dorador, bruñidor, satinador y grabador junto con los mozos de almacén y los encargados de la administración ${ }^{71}$. Además de trabajadores especializados la fábrica de Santa Isabel empleo niños expósitos que residían en el Hospicio de Vitoria y salían a aprender un oficio a éste y otros establecimientos industriales ${ }^{72}$. Lo mismo ocurrió en otras ciudades españolas y extranjeras donde este tipo de comportamiento se asumía dentro de las políticas paternalistas de beneficencia y "caritativas" de la sociedad del momento $^{73}$. Se mantenían vivas las ideas de ilustradas que defendía la función educativa de estos hospicios considerados "las escuelas caritativas de los desvalidos" que estos niños empleados en distintas fábricas sirvieron de mano de obra barata con interminables horarios laborales.

La fabricación artesanal con impresiones de moldes de madera estaba siendo poco a poco sustituida por maquinaria más moderna basada en planchas, cilindros y otras tecnologías que permitían producir de forma algo más industrial. Este proceso de modernización se vivió en la mayor parte de las fábricas nacionales como en Las Maravillas de Madrid dirigida por Casimiro Mahou y heredera de la Real Fábrica de papeles pintados o las de Sebastián Wais (La Coruña), Diego Delicado y Compañía (Vélez-Málaga), Berts-Chinger y Codina (Barcelona) o Viuda de Ribed e Hijo de Villava (Navarra) ${ }^{75}$. Este mismo camino se tomó en la fábrica de Santa Isabel donde contaron con "todas las máquinas conocidas en el extranjero para tirar dibujos a presión mecánica y cilindro y dar toda clase de lustres y brillos además de satinados y barnizados" ${ }^{36}$. Emplearon en la fabricación de papel pintado planchas de madera y de bronce compradas en Francia, una máquina para estampado, varios cilindros también de bronce, además de un bruñidor y un aparato empleado en

71 En base a los ofcios de la Real Fábrica de Papeles Pintados de Madrid y de la fábrica Viuda de Ribed e Hijo de Pamplona ROSE-DE VIEJO, I.: op. cit., pp. 49-51. CAVEDA y NAVA, J.: op. cit., p. 406

72 MADOZ, P.: op. cit., pp. 209-210. En el hospicio hay una fábrica de mantas de muy buena calidad. SAGARNA, I. M.a; MAÑUECO FRANCOS, A.: op. cit., p. 76. Otra fábrica que empleaba niños expósitos en Vitoria fue la de mantas de la calle Pintorería.

73 ROSE-DE VIEJO, I.: op. cit., pp. 32-33, 44, 48. Real Fábrica de Papeles Pintados de Madrid también empleaba niños huérfanos mayores de 10 años, al igual que las fábricas francesas.

74 RODRÍGUEZ CAMPOMANES, P.: Discurso sobre el fomento de la industria popular, Madrid, imprenta Antonio Sancha, 1774

75 CAVEDA y NAVA, J.: op. cit., p. 405. ROSE-DE VIEJO, I.: op. cit., p. 196-197. CANALS AROMÍ. M. T. "Principales centros..., op. cit., p. 76-79. Hay otros ejemplos de modernización en España descritos en este trabajo.

76 MADOZ, P.: op. cit., pp. 209-210. 
"gofrear y atafiletar"77. Algunos materiales empleados en este establecimiento procedían de otras empresas españolas o eran importados de Francia o Alemania. No obstante, la cola se fabricaba en la misma fábrica aunque algunos pigmentos y matices se compraban en el país. Uno de los mayores problemas que tuvo fue "la dependencia en que se encontraba del extranjero en el ramo de colores por no haber en toda la nación fábrica alguna de este género". Por ese motivo decidieron establecer en el mismo edificio "otra de colores bajo la dirección de un aventajado químico y cuyos productos en nada desmerecen de los mejores que se elaboran en las más acreditadas fábricas de colores de París"78. El papel era otra de las materias primas esenciales por lo que se traía mayoritariamente de Tolosa (Gipuzkoa). E oro falso se comercializaba en libritos y procedía de Alemania, "el paño molido y de varios colores" de París y la leña para los hornillos y estufas de los bosques locales ${ }^{79}$. Los costes anuales de las materias primas empleadas eran los siguientes:

\begin{tabular}{|l|l|}
\multicolumn{1}{c}{ Costes anuales de las materias primas } & \multicolumn{1}{c|}{ Precios } \\
\hline Papel de la fábrica de Tolosa (Gipuzkoa) & 55.500 reales \\
\hline Cola para la preparación de los colores & 2.400 reales \\
\hline Oro falso importado de Alemania & 4.000 reales \\
\hline Paño molido y de varios colores de París & 4.000 reales \\
\hline Colores y matices de todas clases & 36.000 reales \\
\hline Leña del país & 1.200 reales \\
\hline Suma & $\mathbf{1 0 3 . 1 0 0 ~ r e a l e s ~}$ \\
\hline
\end{tabular}

Cuadro 1: Coste anuales de las materias primas y precios (CAVEDA y NAVA, J.: op. cit., p. 413.)

77 CAVEDA y NAVA, J.: op. cit., p. 412. RODRÍGUEZ LASO, M. ${ }^{a}$ D.: El arte y la ciencia de la mano... op. cit. P. 9. El papel gofrado tenía relieve por lo que para su impresión se necesitaban dos placas, una positiva y otra negativa.

78 El Heraldo Alavés, 1848

79 CAVEDA y NAVA, J.: op. cit., p. 413.
Los productos fabricados fueron de bastante calidad a juzgar por los comentarios de la época: "hemos tenido el placer de examinar muy detenidamente este establecimiento fabril y no hemos podido menos que admirar lo acabado y perfecto de sus primeras obras. Estas pueden competir sin duda con las que nos envían los franceses"; "son tan bien pintados y de tanto gusto y moda como los que se trabajan en las más acreditadas fábricas del extranjero" "80; "nada desmerecen de los más acreditados de las fábricas de París" ${ }^{\prime 1}$. Aunque también produjeron algunos papeles de menor calidad y más económicos, "de dibujo vulgar y amanerado, de un falso colorido y de un claro-oscuro falto de vigor y de efecto" $\$ 2$. Lo cierto es que se vieron con dificultades para producir productos muy elaborados y costosos, no por falta de medios, sino por la feroz competencia de los llegados del extranjero "libres de derechos"

La presencia en España de papel pintado importado o incluso introducido de manera fraudulenta, fue muy común debido a los continuos cambios en las leyes de comercio exterior y a la inestable política de aranceles que se mantuvo a lo largo del siglo XIX ${ }^{84}$. Fueron muchos los industriales del sector los que, como ya hemos visto en el caso alavés, pidieron políticas proteccionistas, apoyados por intelectuales como Ramón Ortiz de Zárate que opinaba lo siguiente,

"nosotros creemos que la reforma que quiere hacerse en los aranceles es una transición demasiado rápida, pues se reduce a pasar de la prohibición al libre comercio..."; "si el gobierno quiere que se aclimate en España la industria del papel pintado, debe ampararla con su protección sosteniendo la prohibición por algún tiempo más hasta tanto que se desarrolle y cobre vigor y fuerza. Cuando llegue ese día, que no se hará esperar mucho tiempo, puede abrirse francamente el mercado español a los papeles pintados extranjeros" $\$ 15$

80 El Lirio, tomo 2. ${ }^{\circ}$, n. ${ }^{\circ} 16$ (22 de agosto de 1846 ).

81 MADOZ, P.: op. cit., pp. 209-210.

82 CAVEDA y NAVA, J.: op. cit., p. 412.

83 Ibid., pp. 412-413. Incluso habían pensado en producir colores para surtir a otros establecimientos similares, pero la rebaja de los aranceles a los productos llegados del extranjero les había hecho replantearse la idea puesto que no podía competir con sus precios.

84 CANALS AROMÍ. M. T.: "Exportación de los papeles pintados...., op. cit., p. 152. "En nuestro concepto, son bastante módicos y arreglados, dichos precios, con lo que no solo se evitará el contrabando que hasta ahora se ha hecho con el papel pintado francés, sino que además se generalizará su uso entre nosotros"

85 El lirio, tomo $2 .^{\circ},{ }^{\circ} 1$ (1 de mayo de 1846$)$, p. 8. 
En el País Vasco son muchos los ejemplos de papeles pintados importados, probablemente uno de los conjuntos más conocidos y espectaculares sea el de la torre de los Varona en Villanañe (Álava), pero también podemos destacar los de la casona Churruca-etxea en Azkoitia (Gipuzkoa), palacio Arratabe de Aretxabaleta (Gipuzkoa) o los de Gastañaduy en Eskoriatza (Guipúzcoa) entre otros ${ }^{86}$. También disponemos de algunos datos documentales que confirma la llegada de papeles importados a estas tierras. En concreto, en 1822 se tomaba la decisión de decorar distintas estancias de la casa de la Diputación de Álava ${ }^{87}$ En estos registros se enumeran los papeles empleados, fondos, cenefas y frisos, siendo significativo que uno de ellos fuera un panorámico de "vistas de París". Los papeles los proporcionaba la tienda de María Vicenta de Boneta y de su colocación con algunos trabajos de pintura se encargaba el pintor francés Juan Raison ${ }^{88}$. En 1843 Manuel Ciorraga dirigía una carta a Iñigo Ortes de Velasco Esquibel comentándole que le iban a entregar siete piezas de papel pintado azul y una pieza de papel persa que le habían enviado y que estaban a disposición de Madame Dascarbero ${ }^{89}$. A finales de 1858 para las reformar e techo del antiguo teatro Principal de Vitoria se optó por utilizar papel pintado de París en sustitución de pinturas al óleo ${ }^{90}$.

86 CANALS AROMÍ, M. a T.: "Principales centros..., op cit., pp. 73-80. RODRÍGUEZ LASO M.a D.: "Restauración de papeles pintados..." op. cit., pp. 25-27. RODRÍGUEZ LASO, M. ${ }^{a}$ D.: El arte y la ciencia de la mano ... op, cit. RODRÍGUEZ LASO, M. a D.: "El papel como soporte, .., op, cit, pp. 89-91. RODRÍGUEZ LASO, M. ${ }^{a}$ D.: "Los papeles pintados en Euskadi. op. cit. MARTÍNEZ ÁLAVA, C. I.: op. cit. MARTIARENA, X.: op. cit. DE PABLO ALVA, R.: op. cit.

87 URDAIN MARTÍNEZ, C. M.: Sedes históricas de las Juntas Generales de Âlava en Vitoria y Tierras Esparsas, s. XVI-XIX, Vitoria-Gasteiz, Juntas Generales de Álava, 2015, p. 144. ATHA-FHPA-DH 151-14

88 Ibid., ATHA-FHPA-DH 151-14. Los fondos empleados eran de color blanco, azul turquí, verde, amarillo, rosa y blanco, verde y blanco, color nanquín, escocés y un panorámico de vistas de París. Las cenefas aterciopeladas, jaspeadas y de otros colores. El coste total de los papeles y de otros materiales fue de 5327

89 FSS-AMA-VELASCO C 144 N.10 (18 de diciembre de 1843) "He recibido 10 piezas de papeles con tos números 1232 y otra con el num 1236 incluso un pedazo de cenfa de nistos que quedan en mi poder hasta nuestra conformidad, Vitoria, 6 de 1845. Vicente Junguitu"

90 CENTENO ALBA, J. C.: Los teatros y cines de Vitoria. Arquitectura para el espectáculo, Vitoria-Gasteiz Ayuntamiento de Vitoria-Gasteiz, 1999, p. 145. Los bocetos para las pinturas al óleo sobre bastidores lo habían hecho Juan Ángel Sáez y Pablo Bausac.
La materia prima empleada en Santa Isabel de Vitoria procedía principalmente de la prestigiosa fábrica de La Esperanza ubicada en Tolosa (Gipuzkoa) ${ }^{91}$ donde a partir de 1841 se producía papel continuo para distintos $u \operatorname{sos}^{92}$. Se empleaban anualmente entre 50 o 65 rollos, lo que equivalía a 80 o 90 cargas $^{93}$. El material empleado era calificado como "ordinario" diferente del "fino" utilizado para escribir. La cantidad recibida por Santa Isabel era tanta como todas las que llegaban a Vitoria de papel fino, pero igualmente los dos géneros eran cargados con aranceles a su llegada a la Alhóndiga. Los propietarios de la fábrica argumentaban que éste último no requería de ninguna preparación para su uso mientras que el ordinario enviado en rollos necesitaba de una elaborada fabricación y muchos empleados especializados ${ }^{94}$. El papel blanco llevaba "una preparación exclusiva" que se le daba en la misma fábrica, y necesitaba de pinturas y herramientas "para pintar

91 CAVEDA y NAVA, J.: op. cit., p. 413. CANALS AROMÍ, M. ${ }^{a}$ T.: "Principales centros... op. cit., p. 77. AMVG., 35/014/008 (7 de diciembre de 1847).

92 MADOZ, P.: op. cit., p. 10. Además de la fábrica de papel continuo existía en Tolosa otra de papel mano. CAVEDA y NAVA, J.: op. cit., pp. 397-398. Se presentó a la exposición nacional de 1850 siendo muy bien valorada y reconocida. ASENJO MARTÍNEZ, J. L.: "La primera fábrica de papel continuo de España”, en Investigación y Técnica del papel, n. ${ }^{\circ}$ 6, tomo 2, Madrid, 1965, pp. 569- 574. La fabricación de papel a mano comienza en Gipuzkoa en 1817 en el molino Igarondo. En 1819 continua en el molino Larión Echezarreta y Cía. Otras fábricas guipuzcoanas fueron: Araxes, Amaroz y Ruiz de Arcaute y Cia VALLS I SUBIRA, O.: La historia del papel en España, siglos XVIII-XIX, tomo III, Barcelona, Empresa Nacional de Celulosa, 1978. GUTIÉRREZ I POCH, M.: "La mecanización de la industria papelera española en un contexto europeo (1836-1880), Actas del V Congreso Nacional de Historia del papel en España, Gerona, 2003, pp. 14-15. Destacan en el País Vasco la Tolosana, (1867) y La Primitiva (1868) GÓMEZ OSUNA, R.: "Orígenes y evolución y final del ingenio hidráulico situado junto al puente de la villa de Manzanares El Real, Madrid", Actas del VII Congreso Nacional de Historia del Papel, Madrid, 2007, p. 461. Junto a la fábrica de Manzanares que estaba funcionado a finales de 1838, las de Burgos y La Esperanza de Tolosa de 1841 fueron las pioneras en la producción de papel continuo en España. AJA, G., (et al.): op. cit., pp. 655-664. Herederos de la tradición papelera guipuzcoana son el molino de papel Azpikoetxea (Legazpi), fábrica de papel Patricio Elorza (Legazpi), papelera Araxes (Tolosa). RODRÍGUEZ LASO, M. ${ }^{a}$ D.: El arte y la ciencia de la mano..., op. cit., p. 7. Hacia 1830 se va dejando la confección de papel artesanal para producirse papel continuo de grandes formatos, lo que permitia realizar amplios pliegos de papeles pintados para paredes u otros usos.

93 AMVG., 35/014/008 (11 de enero de 1848). NUEVO ÁBALOS, J. L.: "Aproximación al sistema antivuro de medidas mercantiles del papel artesano", Actas del VII Congreso Nacional de Historin del Papel, Madid, 2007, p. 100. "La carga, como peso que lleva sobre sí la bestia o el hombre, correponde Ma ercancia medida, sino en relación con la comarca; aproximadamente siempre correspondía al peso que podí llevar un animal de carga.

94 AMVG., 35/014/008 (11 de enero de 1848). 
y estampar sobre él los grabados necesarios y de esta manera constituir lo que se llama propiamente dicho papel pintado" 95 . El ayuntamiento decidió examinar el material antes de que la comisión de hacienda tomara una resolución, "para que otros fabricantes o especuladores en otras primeras materias no puedan quejarse de que a esta clase nueva de papel ordinario no se cobre el derecho correspondiente a su precio y destinación". Finalmente se dictaminó que el papel ordinario en rollos de 10 varas de largo para ser pintado debía pagar 6 reales y 30 maravedíes por carga de 12 arrobas, los 5 reales por derechos de alhóndiga y 64 maravedíes de peso real ${ }^{96}$.

La producción de éste establecimiento artístico e industrial fue importante a juzgar por los datos que nos ofrece la prensa local y estudios del momento. Según Madoz y Caveda se producían de 37.000 a 60.000 rollos anuales de "30 pies de largo y 22 pulgadas de ancho" cada uno, lo que ascendía a unos 150.000 reales $^{97}$. Lamentablemente la falta de libros de muestras, planchas o moldes empleados en Santa Isabel no nos permite conocer con precisión los productos que se diseñaban y vendían en el mercado nacional ${ }^{98}$. Por lo que sabemos, se hacía toda clase de papeles pintados de colores muy finos ${ }^{99}$, de fondos variados, con muchos tipos de dibujos, lisados, satinados, sin satinar, barnizados, dorados, plateados, imitaciones de maderas y piedras, como ágatas o mármoles ${ }^{100}$. También disponían de gran variedad de cenefas y frisos para combinar con estos papeles ${ }^{101}$. Existía la posibilidad de hacer diseños a demanda para las habitaciones o los espacios que se quisieran personalizar, pues "en adelante cada uno podra empapelar sus casas con todo el capricho que se antoje.

95 AMVG 35/012/014 (21 de octubre de 1846).

96 AMVG., 35/014/008 (11 de enero de 1848).

97 MADOZ, P.: op. cit., p. 210, CAVEDA y NAVA, J.: op. cit., p. 412. SAGARNA, I. M.a; MAÑUECO FRANCOS, A.: op. cit., p. 76

98 ROSE-DE VIEJO, I. op. cit., p. 114. Esta falta es común a la Real Fábrica y otras muchas en España

99 RODRÍGUEZ LASO, M. ${ }^{a}$ D.: El arte y la ciencia de la mano..., op. cit., p. 7. El color estaba constituido por la unión de pigmento, ligante y espesante. Los pigmentos habitualmente empleados eran de origen mineral, vegetal o animal. Se usaban al temple diluidos en agua con un ligante de cola. Se imprimían primero los tonos medios, luego los oscuros y por último los claros. También se hacían estampaciones de un solo tono, aunque las posibilidades podían ser infinitas.

100 ATHA-FHPA-DH-786-1 (mayo de 1847). Entre las muestras de papeles fabricados en Santa Isabel que se presentaban al ayuntamiento para enviar a la Exposición Pública Nacional se encontraban "diferentes rollos de papel pintado y satinado sobre todos fondos de gustos varidos entre ellos algunos atecioplos de papel pinto ýs de pelados y dorados adenás de tres pancles de diferentes decoraciones del genero colorido y estuco co sus correspondientes motivos en los centros, dos de los cuales correspondían a la clase aterciopelados y dorados y la tercera plateadas".

101 El Lirio, tomo 2. ${ }^{\circ}$, n. ${ }^{\circ} 16$ (22 de agosto de 1846). MADOZ, P.: op. cit., p. 210. ATHA-FHPA-DH-786-1, (1847).
Ya no tendra que conformarse nadie, en este punto, con el gusto de fabricante"102. Estos paisajes "tan de moda en la actualidad" eran realizados a mano, sin planchas, de ahí su elevado precio, pero la competencia extranjera hizo que su producción fuera a demanda ${ }^{103}$.

Es difícil por el momento saber con precisión los modelos empleados en Santa Isabel pero probablemente fueran muy parecidos a los que se realizaban en el resto de Europa. Es probable que se fabricaran papeles de raigambre clásica o "a la antigua", como marmoleados, jaspeados, festones, guirnaldas, grecas, mascarones, hojas de acanto, diferentes frisos o bandas o incluso esculturas greco romanas siguiendo las modas neoclásicas, todavía muy presentes en los años en los que estuvo en funcionamiento esta fábrica. También debieron de producirse imitaciones de telas y bordados con realces de oro y plata como tradicionalmente se había hecho en el ámbito de la policromía de imágenes y en otras especialidades artísticas ${ }^{104}$. No pudieron faltar motivos geométricos, repetitivos, florales, arabescos, chinescos, mitológicos, paisajes o escenas panorámicas de todo tipo, tan de moda en el siglo XIX. Mayormente los modelos empleados en Santa Isabel buscaban imitar "los más modernos de la capital de Francia"105, lo mismo ocurría en la Real Fábrica y en otros establecimientos similares, por lo que en ocasiones muchos de los papeles que se están clasificando como importados, en base a comparativas formales, pudieron ser realizados por manufacturas nacionales ${ }^{106}$. Algunos de los pliegos salidos de fábrica Santa Isabel se marcaban con el sello de la empresa, como se pude ver en los conservados en el dormitorio principal de la torre de los Varona en Villanañe (Álava). Tiene forma ovalada y en su interior se puede leer el siguiente lema "FABRICA DE PAPEL/ PINTADO/ DE/ SANTA YSABEL/ DE VITORIA."107(Fig. 6).

102 Ibid

103 MADOZ, P.: op. cit., p. 210

104 RODRÍGUEZ LASO, M. ${ }^{\text {a D.: }}$ El arte y la ciencia de la mano..., op. cit., p. 3. En el siglo XVIII alguno estampadores de telas pasaron a la estampación de papel. CANALS AROMÍ, M. ${ }^{a}$ T.: "Decoraciones murales: similitudes entre iconografías en papeles pintados y tejidos estampados", Datatéxtil, n. ${ }^{\circ} 25$, 2011, pp. 58-73. ÁGREDA PINO, A.: "Entelar el muro: los revestimientos textiles en la arquitectura occidental” en GÓMEZ URDÁÑEZ, C.: Sobre el color en el acabado de la arquitectura histórica, Zaragoza, Universidad de Zaragoza, 2013, pp. 273-330.

105 El Lirio, tomo 2. ${ }^{\circ}$, n. ${ }^{\circ} 16$ (22 de agosto de 1846).

106 ROSE-DE VIEJO, I.: op. cit., p. 114

107 Este sello fue descubierto durante el proceso de restauración llevado a cabo por un equipo bajo supervisión del Servicio de Restauración de la Diputación Foral de Álava a partir de febrero de 1993 en tres fases: arrancado de papeles, restauración (1993-1996) y recolocación (1996-1997). RODRÍGUEZ LASO, M. ${ }^{a}$ D.; CANALS AROMI, M. . T.: "Localización de papeles pintados... op. cit., pp. 283-286. 


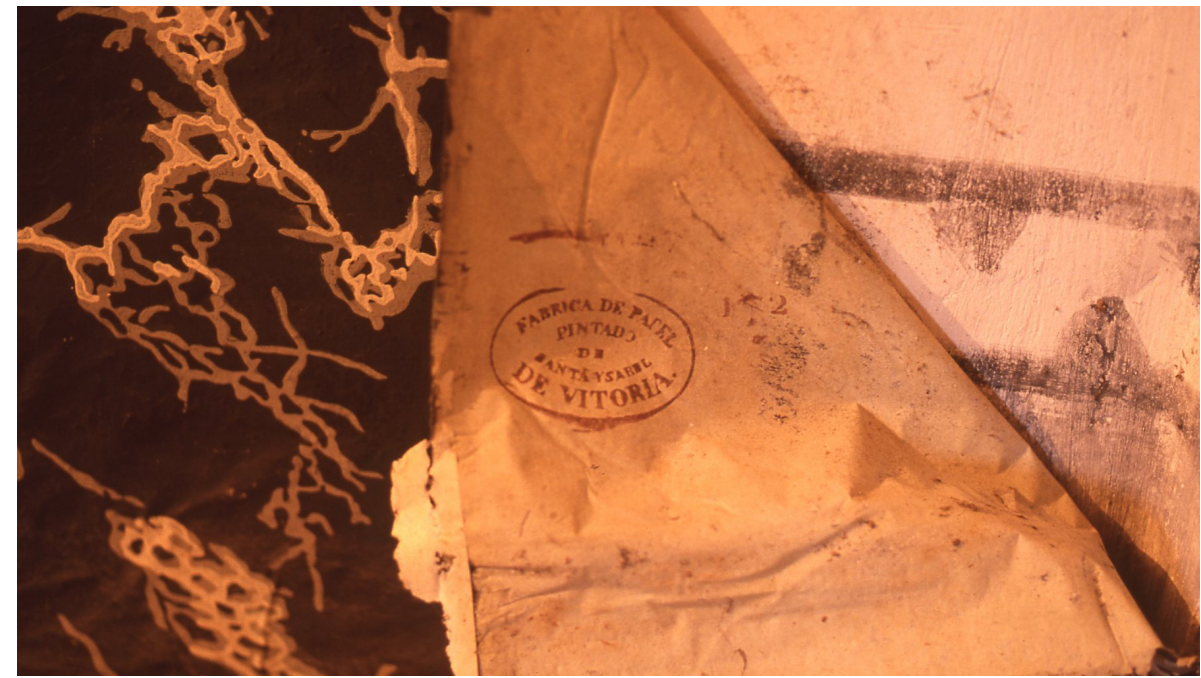

Fig. 6: Sello fábrica de papel. Torre de los Varona. Servicio de Restauración DFA

Los precios podían variar mucho según la elaboración del producto, aunque en base a los datos que nos ofrece la prensa local eran "bastante módicos y arreglados", "con lo que no solo se evitara el contrabando que hasta ahora se ha hecho con el papel pintado frances sino que ademas se generalizara su uso entre nosotros"108. Los más baratos podían llegar a costar de 5 a 8 reales y los más caros 72 reales el rollo, a parte los realizados por encargo cuyo precio venía determinado por lo elaborado del papel ${ }^{109}$. Disponían de facturas que entregaban al cliente con el siguiente membrete, "Fábrica de Papel Pintado, satinado, apañado, dorado y de paisaje para vestir habitaciones, denominada Santa Isabel de Vitoria". En la factura se incluía el nombre del comprador y el número de la misma. "Total del contenido", donde se especificaba el número de rollos. "Clases y fondos de papel", donde se concretaba el tipo de papel y si se trataba de fondo, cenefa o zócalo. "Número de la clase" de catálogo o libro de modelos con el que se diferenciaban los distintos papeles. "Precios" en reales y maravedíes. "Total" o importe final y fecha de la compra con la firma del administrador Saturnino de Ormilugue (Fig. 7)

108 El Lirio, tomo 2. ${ }^{\circ}$, n. ${ }^{\circ} 16$ (22 de agosto de 1846).

109 Ibid.

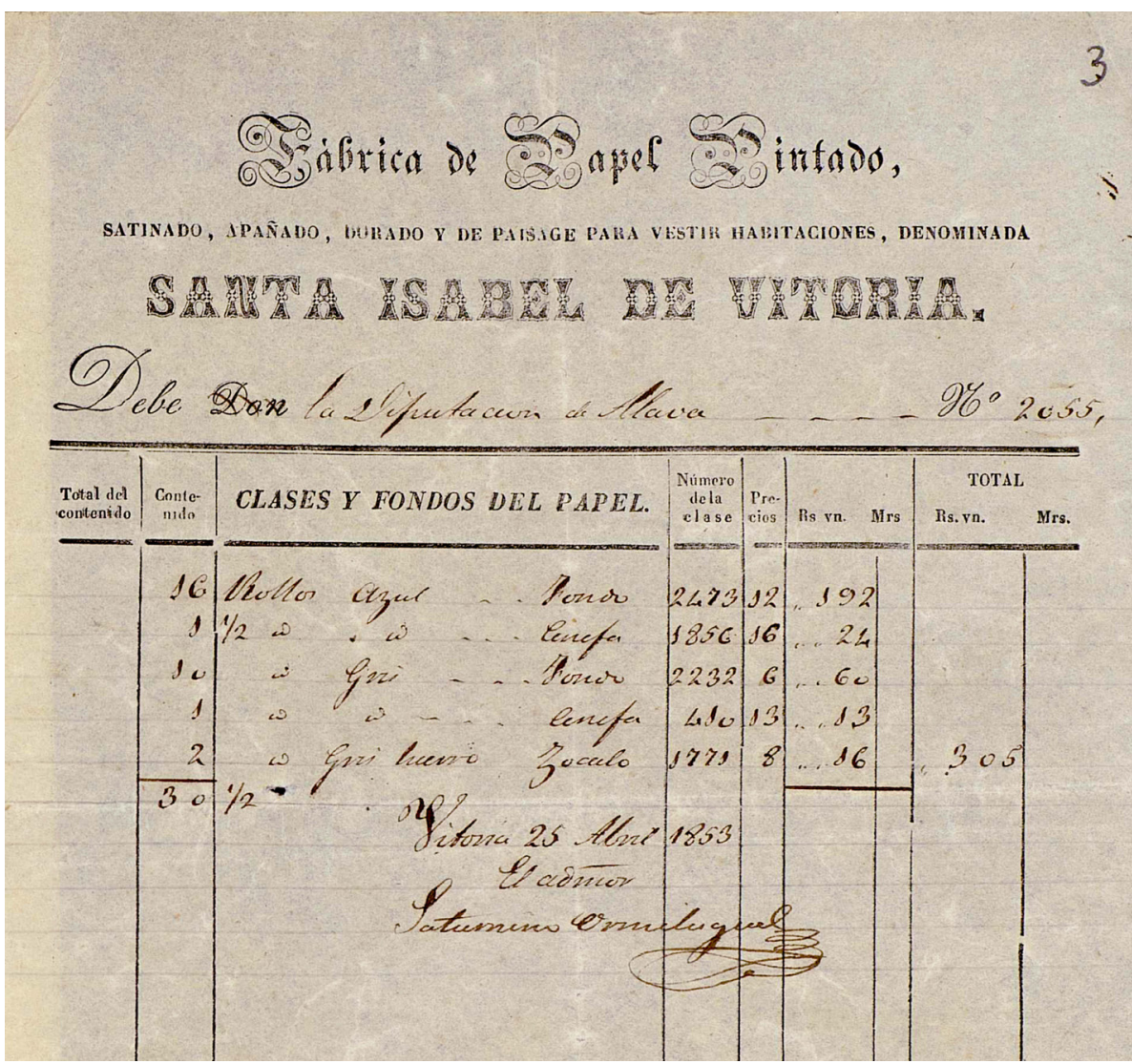

Fig. 7: Factura de la fábrica de Santa Isabel. ATHA-FHPA-DH-1753-6-02 


\section{Modelo}

\begin{tabular}{|l|l|l|}
\hline De todo tipo de fondos y dibujos & $\begin{array}{l}21,5 \text { a } 22 \text { pulgadas de anchura y } \\
\text { de } 30 \text { pies de largura }\end{array}$ & De 5 a 8 reales \\
\hline $\begin{array}{l}\text { De todo tipo de fondos y dibujos, más } \\
\text { finos y satinados }\end{array}$ & $\begin{array}{l}23,5 \text { a } 24 \text { pulgadas de anchura y } \\
30 \text { pies de largura }\end{array}$ & De 10 a 18 reales \\
\hline $\begin{array}{l}\text { Barnizado, aterciopelado, plateado, } \\
\text { dorado y de decoración }\end{array}$ & $\begin{array}{l}23,5 \text { a } 24 \text { pulgadas de anchura y } \\
30 \text { pies de largura }\end{array}$ & De 28 a 72 reales \\
\hline
\end{tabular}

Cuadro 2: Modelos, dimensiones y precios [El Lirio, tomo 2. ${ }^{\circ}$, n. ${ }^{\circ} 16$ (22 de agosto de 1846)]

Los productos terminados se vendían en Vitoria, en los almacenes de la fábrica y en todas las provincias de España desde las que se hacían pedidos diariamente. Además en algunas ciudades como en Madrid, había delegaciones de éste establecimiento, en concreto en la calle Montera 24 en el almacén de Braulio Yerro ${ }^{110}$. Incluso en determinados géneros se hacían promociones de hasta un $30 \%$ de rebaja en el precio ${ }^{111}$. Lo más probable es que, como la Real Fábrica de Madrid, empleara distintas estrategias comerciales, disponiendo de representantes en otras ciudades, invitado a sus clientes a visitar la fábrica o con otras provechosas tácticas de marketing ${ }^{112}$. No hay datos precisos, pero es probable que también vendieran sus productos a las colonias de ultramar como hacían algunas fábricas catalanas ${ }^{113}$. Los papeles que se fabricaban en Santa Isabel tenían como principal destino las distintas habitaciones y aposentos de las viviendas, pero también realizaban decoraciones para teatros, para cubrir los fogones de las chimeneas o biombos, entre otros productos ${ }^{114}$ Además se debieron emplear para revestimiento de armarios, puertas, arcones, cofres y otros objetos que podían ser susceptibles de ser empapelados ${ }^{115}$.

110 El Lirio, tomo 2. ${ }^{\circ}$, n. ${ }^{\circ} 16$ (22 de agosto de 1846). MADOZ, P.: op. cit., pp. 210. CAVEDA y NAVA, J.: op. cit., p. 413. SAGARNA, I. M.a; MAÑUECO FRANCOS, A.: op. cit., p. 76

111 MADOZ, P.: op. cit., pp. 210.

112 ROSE-DE VIEJO, I.: op. cit., p. 44.

113 CANALS AROMÍ, M. a T.: "Exportación de los papeles pintados..., op. cit., pp. 151-155.

114 El Lirio, tomo 2. ${ }^{\circ}$, n. ${ }^{\circ} 16$ (22 de agosto de 1846). MADOZ, P.: op. cit., pp. 210.

115 RODRIGUEZ LASO, D., (et. al.): "El papel como soporte..., op. cit, p. 91
El uso de papeles pintados como revestimiento mural se fue generalizado a lo largo del siglo XIX, convirtiéndose en un complemento decorativo imprescindible en las casas de las élites y entre las clases medias, que ya podían acceder a productos más económicos pero también de cierta calidad. Por ese motivo en la prensa local vitoriana se hacían algunas recomendaciones para su correcto uso. Se advierte a los consumidores que los papeles más baratos, de precios inferiores a 2 reales el rollo, destiñen y manchan lo que tocan con gran facilidad. En las habitaciones se debían evitar los colores demasiado vivos para impedir reflejos desagradables. En los salones se recomendaban los papeles aterciopelados y para las pequeñas alcobas se consideraba mejor sustituir el papel por estucados o charolados. En los gabinetes o en el tocador se podían emplear motivos más atrevidos, con dibujos caprichosos, y en los pasillos y corredores se aceptaban bien los de rayas o listas ${ }^{116}$. También resultaba importante advertir que si las paredes eran húmedas convenía cubrirlas de bastidores con lienzos y sobre ellos colocar el papel ${ }^{117}$. Había que tener especial cuidado con los pintados de verde, o verde gris, porque disponían de acetato de cobre, un producto que se desprendía con facilidad al ser limpiado quedando inerte en el ambiente ${ }^{118}$. Por ese motivo se avisaba de que "Por pequeña parte que fuera la dosis del acetato de cobre introducida de esta manera por las vías digestivas y respiratorias basta para producir envenenamientos en los niños y en personas adultas de temperamento delicado"119. Por este motivo se recomendaban los papeles charolados, ya que aunque se frotaran no se desprendía de ellos ninguna partícula nociva para la salud. Resultaban además más fáciles de limpiar, "porque el polvo no se adhiere a ellos y se les limpia perfectamente con un plumero o por medio de una esponja ligeramente húmeda"120.

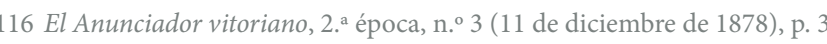

117 De manera similar, sobre bastidores, se colocaban los papeles chinos importados. De esta manera se evitaban humedades aunque se añadían las desventajas derivadas de la madera, por la acidez de la misma. HOSKINS, L.: op. cit., p. 46. RODRIGUEZ LASO, D. (et. al.), "El papel como soporte..., op. cit, p. 91.

118 El Anunciador vitoriano, 2. ${ }^{a}$ época, n. ${ }^{\circ} 3$ (11 de diciembre de 1878), p. 3. En la actualidad el acetato de cobre tiene gran variedad de utilidades aunque presenta riesgos importantes para el ambiente y la salud. 119 Ibid.

$120 \mathrm{Ibid}$. Los papeles aterciopelados, dorados y plateados cuestan desde 4 y 5 reales hasta 40 y 50 reales. Los precios de las panorámicas con paisajes u otros motivos varían respecto la riqueza y la perfección del trabajo. La longitud de los rollos suelen ser de 8 metros mientras que el ancho es variable, aunque el habitual es de $6,50 \mathrm{~m}$. 


\section{EL OCASO DE LA FÁBRICA}

A pesar del creciente éxito en el consumo de papeles pintados a lo largo del siglo XIX muchas de las fábricas que se abrieron tuvieron un recorrido vital no demasiado largo. Es probable, como apunta la profesora Canals Aromí que no supieran adaptarse con éxito a las nuevas formas industriales de producción y que no pudieran aguantar la competencia extranjera $^{121}$. La fábrica de Santa Isabel de Vitoria dejó de funcionar en la década de los 60. Según Sagarna y Mañueco fueron dos los motivos de su cierre, el primero la reforma de los aranceles, por lo cual no pudieron competir con sus semejantes, y el segundo y fundamental fue la falta de rentabilidad, puesto que las ventas eran menores que el coste de fabricación ${ }^{122}$. Lo cierto es que Saturnino de Ormilugue tuvo que reclamar distintos impagos en la compra de papel pintado de Santa Isabel. Por ejemplo en 1857 concurre al concurso de acreedores sobre el vecino de Madrid, José María Orallo por 7087 r y 41 céntimos que estaba debiendo a la fábrica ${ }^{123}$.

En el Anuario General del Comercio de 1863 todavía aparecen publicitados, pero en la Exposición vitoriana de Bellas Artes inaugurada en abril de 1867 por iniciativa de la Academia de Bellas Artes ya no están presentes mostrando sus trabajos, lo que indica que su producción había cesado ${ }^{124}$. Algo que resulta extraño pues siempre habían tenido preocupación de asistir a este tipo de eventos donde mostrar sus productos. En 1847 Saturnino de Ormilugue, administrador de la fábrica de Santa Isabel, presentaba al ayuntamiento de Vitoria y a la Diputación Foral de Álava varias muestras de papel pintado para que fueran examinadas, a fin de que se pudieran enviar a la Exposición pública Nacional que se iba a celebrar en Madrid. Según sus palabras "el movimiento industrial y fabril que distingue a las sociedades modernas ha comenzado a dar los primeros frutos en Yberia"125. También en la Exposición Nacional de 1850 celebrada en Madrid, del 1 de octubre al 31 de diciembre, estuvieron presentes con muestras de su producción e incluso Caveda en su catálogo le dedicó numerosos elogios a esta joven empresa ${ }^{126}$.

121 CANALS AROMÍ, M. ${ }^{a}$ T.: "Principales centros... op. cit., p. 79. ROSE-DE VIEJO, I.: op. cit., p. 199. La competencia europea también afectó al cierre de la fábrica Las Maravillas en 1856

122 SAGARNA, I. M.a; MAÑUECO FRANCOS, A.: op. cit., p. 76.

123 AHPA., Antonio Cerain, 13510, 1857, fol. 918. 1 de diciembre de 1857. Da su poder a don Antonio

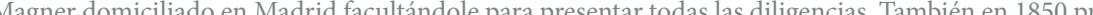
(a) de Andoin, 13593, 1850, fols. 13-14. (22 de Junio de 1850).

124 BECERRO DE BENGOA, R.: op. cit., pp. 198-206.

125 ATHA-FHPA-DH-786-1 (5 de mayo de 1847).

126 CAVEDA y NAVA, J.: op. cit., pp. 411-413. CANALS AROMÍ. M. T.: "principales centros..., p. 76.
Como ya hemos comentado es en los primeros años de la década de los 60 cuando la fábrica deja de estar en funcionamiento. Su administrador y principal valedor, Saturnino de Ormilugue moría en 1870 con 63 años, sin que en su testamento se haga mención alguna a este establecimiento ${ }^{127}$. A partir de los años 70 los papeles pintados llegan a Vitoria de otras fábricas nacionales e internacionales y se distribuyen a través de droguerías y tiendas de pintura. Serán por tanto los pintores-decoradores los encargados de su venta y colocación a juzgar por los Registros de Matricula Industrial ${ }^{128}$. En la década de los 80 varios de estos negocios se situaron en la calle Prado, siendo uno de los más reconocidos el almacén de papeles pintados Viuda e hijos de Leveque. No obstante, fueron también otros acreditados pintores como, Epifanio Díaz de Arcaute, Juan Daniel Alba o Lesmes Mesanza, los que complementaban su labor de pincel con tiendas abiertas al público que funcionaban como droguería, decoración, venta de papeles pintados y material relacionado con la pintura ${ }^{129}$. Será a principios del siglo XX cuando se comienzan a notar ciertas tiranteces entre comerciantes de papeles pintados y artículos de droga de Vitoria y el gremio de pintores decoradores, sobre si estos últimos podían disponer en sus tiendas artículos que no fueran precisos para su oficio ${ }^{130}$. En estos años siguen siendo los pintores con almacenes o tiendas de pintura y decoración los encargados de vender y colocar los papeles pintados ${ }^{131}$. En estos negocios también se comercializaban productos de droguería y todo tipo de materiales de pintura caballete, además de realizar restauraciones y trabajos artísticos ${ }^{132}$ (Figs. 8-9).

27 SANTOYO, J C:

28 ATHA-FHPA-DAH 1626-1. 1886-7. Registro de Matricula Industrial (1886-7). Venta al por mayor de droguerías y papel pintado: Joaquín Zuloaga (C/ Pintoreria 26). Nicasio Buesa. (C/ Estación. 2). Gabrie Buesa (C/ Estacion 2). Bonifacio Ruiz Angulo (C/ Estacion 17). Epifanio Ruz de Arcaute (C/ Prado 6 . Josefa Aspe (C/ Prado 20). Lesmes Mesanza. (C/ San Francisco 34). Juan Daniel Alba (C/ Estación 26). Anuario de comercio de 1888 de la provincia de Álava. Papeles pintados: Daniel Alba (C/ San Antoni Viuda de Leveque (C/ Prado 24). Lesmes Manzana (C/ Prado 20).

129 BARTOLOMÉ GARCÍA, F. R.: “Aproximación al pintor Epifanio Díaz de Arcaute (1845-1910)”, Sancho el Sabio, n. ${ }^{\circ} 33,2010$, pp. 123-124

130 ATHA-FHPA-DH 5664-43 (30 de octubre de 1909). "Se acuerda comunicar que estos artículos no son comerciales mientras no se vendan al público y que por tanto pueden utilizarse".

131 CARIOLET, L.: Guía Comercial de Vitoria, Vitoria, Imprenta de Barrutia, 1904, pp. 93, 96, 97. Establecimientos de papeles pintados en 1904: Juan Alba (C/ Sur 4), Laureano Aldecoa (C/ Oriente, 6), Epifanio Díaz de Arcaute (C/ Prado 26) Ciriano y Pérez (C/ Florida 14) Juan Estívariz (C/ General Álava 5) Guía regional Aragón Catahña Navarra Rioja provincias vascongadas, Zaragoza, 1917. Almacenes Papeles pinl Aroson Ca17: Jun Papeles pint Dato, 28), Juan Estivariz (C/ General Alava, 5) Emilio Leveque (C/ General Alava, 7), J. Linacero (C/ Independencia, 7), Simón Pérez (C/ Florida 14), Aniano Zuñeda (C/ San Antonio, 27).

132 COLA Y GOITI, J.: La ciudad de Vitoria, Vitoria, Viuda e hijos de Iturbe, 1883. COLA Y GOITI, J. 


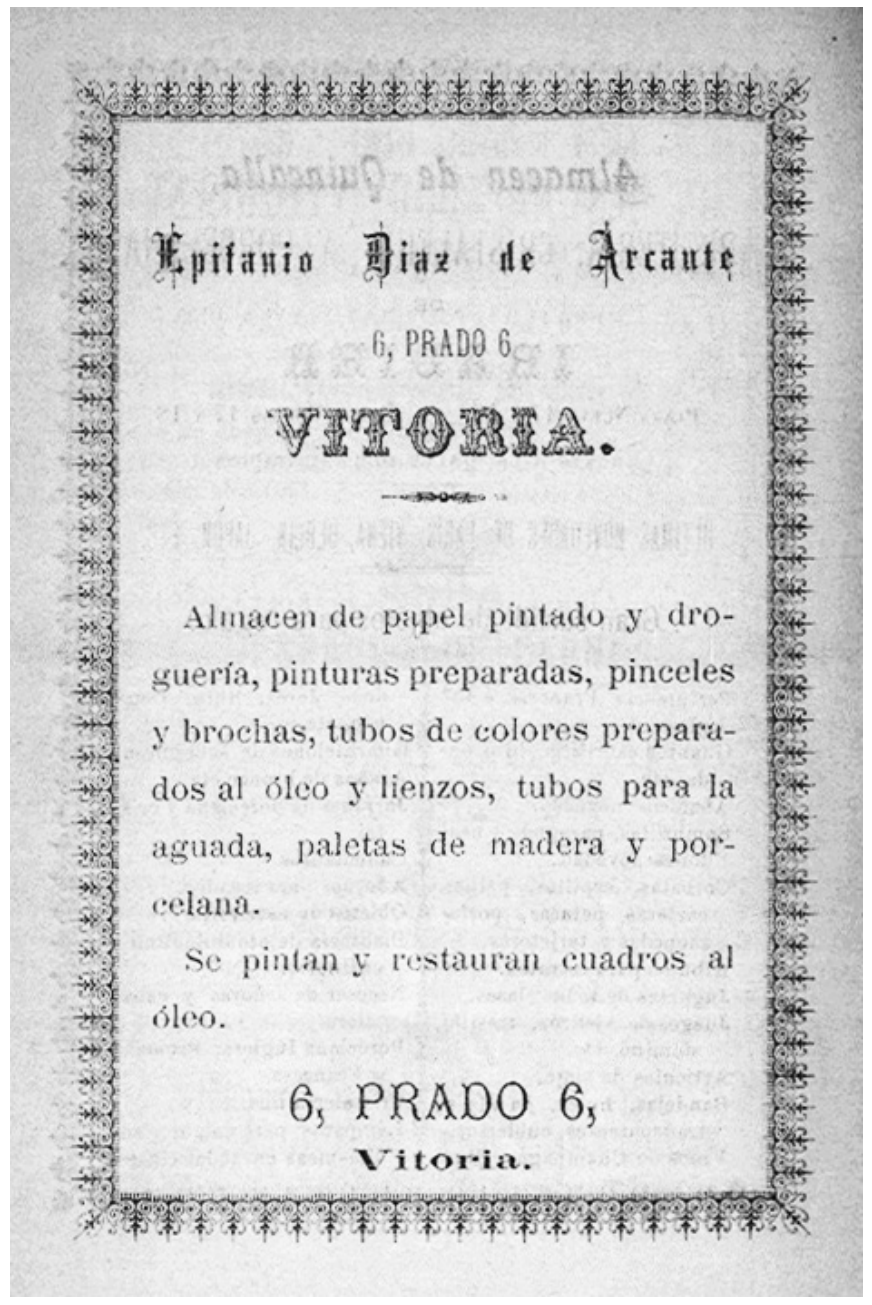

Fig. 8: Anuncio del pintor Epifanio Díaz de Arcaute (COLA Y GOITI, J.: La ciudad de Vitoria, Vitoria, Viuda e hijos de Iturbe, 1883.)

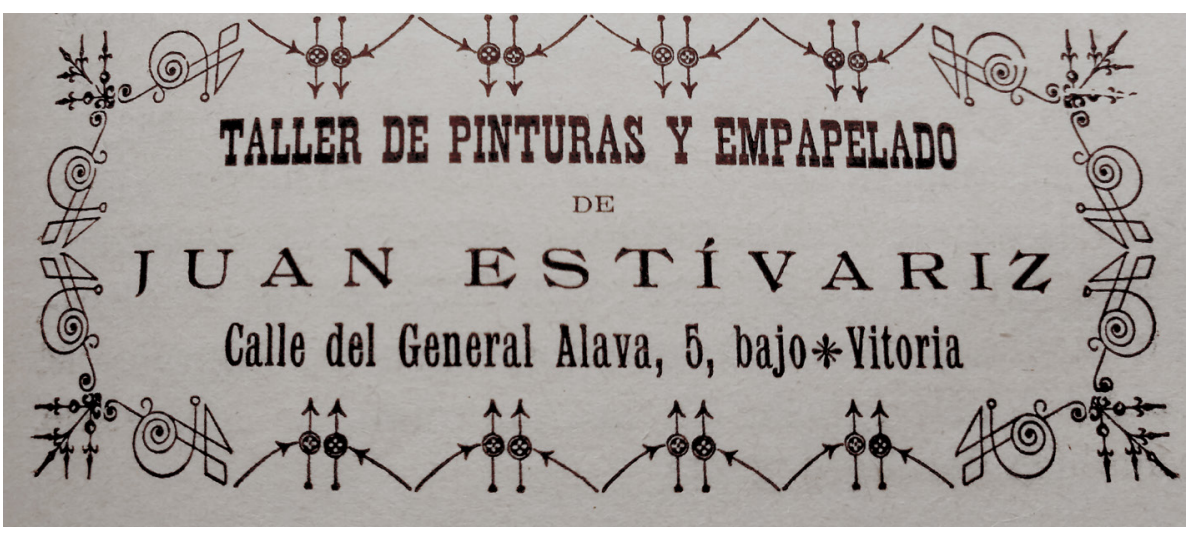

Fig. 9: Anuncio del pintor Juan Estívariz (COLA Y GOITI, J., Guía de Vitoria, Viuda e hijos de Iturbe, 1901.)

\section{EJEMPLOS DOCUMENTADOS Y CONSERVADOS}

Lamentablemente, no disponer de los libros de cuentas ni de muestras de la fábrica de Santa Isabel no nos permite conocer a ciencia cierta la producción real y los modelos empleados por este establecimiento. La fragilidad del material y los continuos cambios de gusto han hecho que sean muy escasos los restos que por el momento han llegado hasta nuestros días. Es probable que con el tiempo aparezcan nuevos pliegos con los que poder conocer mejor las creaciones de esta fábrica. Por el momento sabemos que aunque no fuera rentable tuvo muchos encargos a nivel local y nacional. Como para la compra y colocación de estos papeles no era necesario protocolizar un contrato ante notario y las transacciones eran directas, tan solo quedaban registradas en los desaparecidos libros de cuentas y en las facturas emitidas, difíciles de localizar en los archivos públicos y privados. No obstante, tenemos algunas excepciones, vinculadas con las instituciones que nos confirma que también ellas se sumaron decididamente al uso decorativo de estos productos.

El 25 de abril de 1853 se facturaba a la Diputación Foral de Álava la cantidad de 305 reales por papel pintado de Santa Isabel. Se compraban para la habitación en la que se realizaban las sesiones de Junta General de Provincia en Villarreal de Álava ${ }^{133}$. De su colocación se encargaba el pintor vitoriano Fermín de Herrera, lo que nos confirma una vez más la

133 ATHA-FHPA-DH-1753-6-02. 
presencia de pintores en estas labores ${ }^{134}$. Cobraba por el material y el trabajo realizado 577 reales, que eran aprobados por la institución para su pago el 9 de junio de 1853, con el visto bueno del arquitecto de la provincia Martín de Saracibar ${ }^{135}$. Se compraron a la fábrica Santa Isabel: 16 rollos azul de fondo $\left(n .^{\circ} 2473\right)$ por 192 reales, un rollo y medio de cenefa azul (n. $\left.{ }^{\circ} 1856\right)$ por 24 reales, 10 rollos de color gris de fondo (n. $\left.{ }^{\circ} 2232\right)$ por 60 reales, 1 rollo de cenefa gris (n. ${ }^{\circ} 410$ ) por 13 reales y 2 rollos de gris huevo de zócalo (n. ${ }^{\circ} 1771$ ) por 16 reales (Fig. 7). Hacia 1850 el antiguo teatro Principal decidió transformar el salón del café en un moderno salón de descanso a la moda del momento, en la que la burguesía vitoriana pudiera relacionarse. Dos años después de su creación se introducen algunos cambios en su decoración interior en un intento de hacerlo más acogedor. Se contrataba a los hermanos Díaz de Arcaute la colocación de "ocho rollos papel fondo, tres tiras de cenefa y un zócalo en la pieza del tocador del baile quincenal". Todos estos materiales procedían de la fábrica Santa Isabel y eran de color "gris con blanco"136.

Donde sí que se conservan muestras de la producción de esta fábrica es en la Torre de los Varona en Villanañe (Álava), en concreto en el dormitorio principal. Se sitúan hacia 1850 y fueron realizados con papel continuo, de impresión mecánica mediante cilindro grabado en relieve y pigmentos inorgánicos ${ }^{137}$. Dispone de zócalo con imitación de mármol negro y veteado blanco. Una cenefa vegetal con cartelas correiformes repetidas rítmicamente de las que nacen flores rosas y azules. El lienzo principal de pared es un papel de fondo blanco cuyo motivo central es una cartela de cueros enrollados o recortados, típicamente manierista de cuyo centro nace un ramillete floral. De todos sus lados crecen finos roleos con centros florales de los que brotan cintas, zarcillos o guías que se unen a conjuntos idénticos repetidos rítmicamente (Fig. 10). El paño se remata en su parte alta con dos cenefas exactamente iguales a las anteriormente descritas. Estos papeles con diseminación

134 BARTOLOMÉ GARCÍA, F R. La policromía barroce en Álava, Vitoria-Gasteiz, Diputación Foral de Álava, 2001, p. 309, 311, 317. BARTOLOMÉ GARCÍA, F. R.: José López de Torre (1755-1829) y la pintura neoclásica en Álava, Vitoria-Gasteiz, Diputación Foral de Álava, 2007, p. 20. Los Herrera fueron una conocida saga de pintores que trabajaron en Álava y alrededores durante el siglo XVIII y primera mitad del XIX.

135 ATHA-FHPA-DH-1753-6-02. El informe de Martín de Saracibar se presentaba el 7 de junio de 1853. 136 CENTENO ALBA, J.C.: op. cit., p. 162. Tiburcio Díaz de Arcaute y su hermano facturaban el 14 de febrero de 1852.

137 CANALS AROMÍ, M. a T.: "Principales centros..., op cit., pp. 73-80. RODRíGUEZ LASO M. ${ }^{\text {a }}$ D.: "Restauración de papeles pintados..." op. cit., pp. 25-27. RODRÍGUEZ LASO, M. ${ }^{a}$ D.: El arte y la ciencia de la mano..., op. cit. RODRÍGUEZ LASO, M. a D.: "El papel como soporte..., op. cit., pp. 89-91. RODRÍGUEZ LASO, M. a D.: "Los papeles pintados en Euskadi..., op. cit. MARTÍNEZ ÁLAVA, C. J.: op. cit MARTIARENA, X.: op. cit. DE PABLO ALVA, R.: op. cit. florales sobre fondos blancos o de otros tonos fueron muy habituales en las producciones francesas de hacia $1850-1855^{138}$. El sello de la fábrica se localiza en el reverso del zócalo con forma ovalada y el siguiente lema "FABRICA DE PAPEL/ PINTADO/ DE/ SANTA YSABEL/ DE VITORIA" (Fig. 5). Las degradaciones observadas se debían al pigmento verde esmeralda conseguido a base de cobres, arsénico y acetato que reacciona con la humedad creando ácido acético y oxidando las fibras de papel ${ }^{139}$.

Para concluir debemos considerar que la fábrica de papeles pintados de Vitoria fue una audaz apuesta industrial, de carácter artístico artesanal, con la que se buscaba crear productos competitivos para el mercado local, nacional y probablemente internacional. Se puso en marcha a imitación de las existentes en Francia, con maquinaria moderna e importada y operarios especializados formados en el país vecino. Su producción fue muy variada, abarcando desde productos básicos a los de gran calidad, con un abanico de precios muy amplio, abierto a todo tipo de clientes, desde las clases medias a las élites con mayor poder adquisitivo. No tuvo un largo recorrido debido a la presión fiscal que tuvo que soportar, tanto en las materias primas como en los productos ya elaborados. A esto había que sumar la competencia extrajera que introducía sus productos en el mercado español bajo cauces legales, pero también de forma ilegal, a través del contrabando, lo que provocó que los precios se desplomaran y que este establecimiento y otros enclavados en el territorio español, no pudieran resistir la competencia. La ausencia de los archivos de la fábrica y de los libros de modelos empleados, no nos permite conocer con precisión el alcance de su producción. Por el momento tan solo disponemos un ejemplo conservado, sin embargo albergamos la ilusión de que con el tiempo irán apareciendo más.
138 NOUVEL, O.: Papiers peints français 1800-1850, Fribourg, office du Livre, 1981, pp. 36-37.

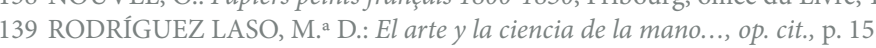




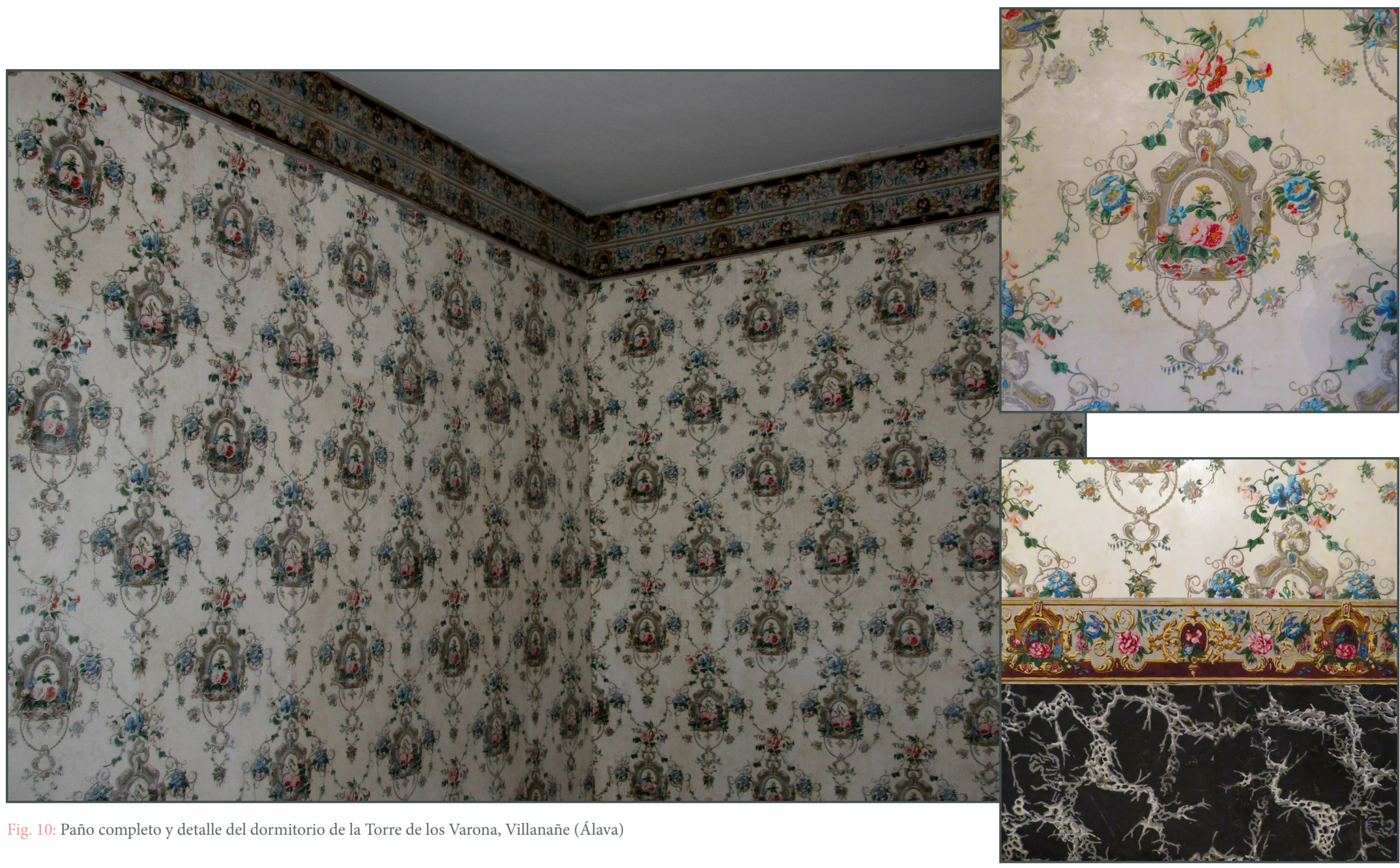




\section{BIBLIOGRAFÍA}

ÁGREDA PINO, A.: "Entelar el muro: los revestimientos textiles en la arquitectura occidental” en GÓMEZ URDÁÑEZ, C.: Sobre el color en el acabado de la arquitectura histórica, Zaragoza, Universidad de Zaragoza, 2013, pp. 273-330.

AJA, G., (et al.): Patrimonio industrial vasco, I-II, Vitoria-Gasteiz, Servicio Central de Publicaciones del Gobierno Vasco, 2012.

ANGULO MORALES, A.: "Entre la promoción y la protección: el banco de emisión y descuento de Vitoria (1863)", en REGUERA, I.; PORRES, R. (eds.): Poder, pensamiento y cultura en el Antiguo Régimen, Actas de la 1. ${ }^{a}$ semana de estudios históricos "Noble villa de Portugalete", Donostia, Eusko Ikaskuntza, 2002.

ASENJO MARTÍNEZ, J. L.: "La primera fábrica de papel continuo de España”, en Investigación y Técnica del papel, n. ${ }^{\circ}$ 6, tomo 2, Madrid, 1965, pp. 569- 574

BARTOLOMÉ GARCÍA, F. R.: “Aproximación al pintor Epifanio Díaz de Arcaute (18451910)", Sancho el Sabio, n. ${ }^{\circ} 33,2010$, pp. 119-133.

BARTOLOMÉ GARCÍA, F. R.: José López de Torre (1755-1829) y la pintura neoclásica en Álava, Vitoria-Gasteiz, Diputación Foral de Álava, 2007.

BARTOLOMÉ GARCÍA, F. R.: La policromía barroca en Álava, Vitoria-Gasteiz, Diputación Foral de Álava, 2001.

BAZÁN, I.; IBÁÑEZ, C.: La cárcel celular de Vitoria, Vitoria-Gasteiz, Ayuntamiento de Vitoria-Gasteiz, 2000.

BECERRO DE BENGOA, R.: El libro de Álava, Vitoria, Hijos de Manteli, 1877.

CANALS AROMÍ, Ma ${ }^{a}$ T.: "Principales centros de fabricación de papel pintado en España a mediados del siglo XIX”, Actas del IV Congreso Nacional de Historia del Papel en España, Cuenca, Asociación Hispánica de Historiadores del papel, 2001, pp. 73-80.
CANALS AROMÍ, M.a T.: "Real Fábrica de papeles pintados, 1788-1834", en TORREGUITART BÚA, S., (coord.): Jornadas sobre Reales Fábricas, La Granja de San Ildefonso. Cuenca, Fundación Centro Nacional del Vidrio, 2004, pp. 395-405.

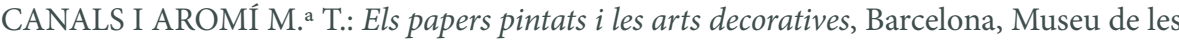
arts decoratives, 2003.

CANALS AROMÍ, M. ${ }^{a}$ T.: "Decoraciones murales: similitudes entre iconografías en papeles pintados y tejidos estampados", Datatéxtil, n. ${ }^{\circ} 25,2011$, pp. 58-73.

CARRASCAL NINGUELA, J. J., (coord.): Cartografía antigua del ayuntamiento de Vitoria (1617-1950), Vitoria-Gasteiz, Ayuntamiento de Vitoria-Gasteiz, 2006.

CAVEDA, J.: Memoria presentada al Excmo. señor Ministro de Comercio, Instrucción y Obras Públicas por la Junta calificadora de los productos de la industria española reunidos en la exposición pública de 1850, Madrid, Establecimiento Tipográfico de D. Santiago Saunaque, 1851.

CENICACELAYA, J.; SALOÑA, I., (et al.): Arquitectura neoclásica en el País Vasco, Bilbao, Departamento de Cultura y Turismo del Gobierno Vasco, 1990.

CENTENO ALBA, J. C.: Los teatros y cines de Vitoria. Arquitectura para el espectáculo, Vitoria-Gasteiz, Ayuntamiento de Vitoria-Gasteiz, 1999.

COLA Y GOITI, J.: La ciudad de Vitoria, Vitoria, Viuda e hijos de Iturbe, 1883.

COLA Y GOITI, J.: Guía de Vitoria, Viuda e hijos de Iturbe, 1901.

DE MAÑARICUA, A. E.: Obispados en Álava, Guipúzcoa y Vizcaya hasta la erección de la Diócesis de Vitoria (28 de abril de 1862), Vitoria, Editorial Eset Seminario Diocesano, 1964 pp. 362-363.

DE PABLO ALVA, R.: Los papeles pintados de la torre de los Varona en Villanañe (Álava), Trabajo fin de grado, curso 2018-19 (bajo la dirección de Fernando R. Bartolomé García). https://addi.ehu.es/handle/10810/30143 (consultado el 15/03/1019). 
DE PABLO, S.; DE LA GRANJA, J.L.; RUBIO POBES, C.: Breve historia de Euskadi, de los fueros a la autonomía, Barcelona, Debate, 2011.

DE PABLOS Y VIEJO, E.; HERRERO CARRETERO, C.; MAÑUECO SANTURTUN, C.: Manufacturas Reales españolas, Madrid, Fundación Fondo de Cultura de Sevilla, Caja Madrid, 1993.

DEL VAL, V.: Calles Vitorianas, Vitoria, Obra cultural de la Caja de Ahorros Municipal, 1979.

EXTRAMIANA GONZÁLEZ, M.: El Cementerio De Santa Isabel De Vitoria-Gasteiz. Proyecto de Fin de Carrera dirigido por Ana de Begoña y Azcárraga (inédito), 2003.

FERNANDEZ DE PINEDO, E.: “De la primera industrialización a la reconversión industrial: la economía Vasca entre 1841 y 1990" en GERMAN, L; LLOPIS, E.; MALUQUER, J.;ZAPATA, S. (eds), Historia de la economía regional de España, siglos XIX-XX, Barcelona, Crítica, 2001.

GÓMEZ OSUNA, R.: “Orígenes y evolución y final del ingenio hidráulico situado junto al puente de la villa de Manzanares El Real, Madrid”, Actas del VII Congreso Nacional de Historia del Papel, Madrid, 2007.

GUTIÉRREZ I POCH, M.: "La mecanización de la industria papelera española en un contexto europeo (1836-1880), Actas del V congreso nacional de Historia del papel en España, Gerona, 2003, pp. 14-15.

HOSKINS, L., (ed.): The papered Wall. The history, petterns and techniques of wallpaper, London, Thames and Hudson, 1994.

HUNTER, D.: Papermaking. The history and Technique of an ancient craft, New York, 1978.

JACQUÉ, B., (et al.): Les papiers peints en arabesques de la fin du XVIIIe siècle, París, Martinière, 1995.

JACQUÉ, J.; WISSE, G.: Le murmure des murs, quatre siècles d'histoire du papier peint, Bruxelles, Studio, 2001

KEIM, K.: El papel, Madrid, Asociación de investigación técnica de la industria papelera española, Madrid, 1966.
LA HOUGUE, V.: "Les fabricants de papiers peint à Lyon de la fin du XVIIIe siècle”, Bulletin de la Société Historique, Archéologique et Littéraire de Lyon, XXXII, 2002, pp. 13-48.

LABORDA YNEVA, J.: El proyecto de arquitectura en la Real Academia de San Fernando: Las pruebas de examen de los aspirantes vascos, 1776-1855, Vitoria-Gasteiz, Servicio Central de Publicaciones del Gobierno Vasco, 2011.

LARUMBE MARTIN, M.: “Tres proyectos neoclásicos para el cementerio de Vitoria”, Kultura, n. ${ }^{\circ}$ 3, 1991, pp. 36-39.

MADOZ, P.: Diccionario geográfico estadístico histórico de España y sus posesiones de ultramar, Madrid, 1845-1850, Edición facsímil de Juntas generales de Álava, Vitoria, 1989.

MAÑUECO FRANCOS, A.: Vitoria en 1850, año de la fundación de la caja de ahorros de la ciudad, Vitoria, Obra cultural de la caja de Ahorros y Monte de la Piedad, 1945.

MARTIARENA, X.: “Papeles pintados, 1835. Eskoriatza, Aretxabaleta, Donostia, Villanañe y Azkoitia”. www.xabimartia.blogspot.com.es/ (Consultado el 12/03/2019).

MARTÍNEZ ÁLAVA, C. J.: La torre-palacio de los Varona: historia y patrimonio. VitoriaGasteiz, Diputación Foral de Álava, 2009.

MOLINA, A.; VEGA, J.: "Adorno y representación: escenarios cotidianos de vida a finales del siglo XVIII en Madrid", Cuadernos dieciochistas, 19, 2018, pp. 139-166.

NUEVO ÁBALOS, J.L.: “Aproximación al sistema antiguo de medidas mercantiles del papel artesano", Actas del VII Congreso Nacional de Historia del Papel, Madrid, 2007, pp. 441-452.

RENFER, CH.: "Fladerpapier et papiers de décor imprimés du XVIe siècle - Aperçu des fonds suisses", en THOMSON, H. B. (Dir.), Papiers peints, poésie des murs. Les collections du Musée national suisse, Zürich, Musée national de Suisse, 2010, pp. 125-137.

RODRÍGUEZ CAMPOMANES, P.: Discurso sobre el fomento de la industria popular, Madrid, imprenta Antonio Sancha, 1774 
RODRÍGUEZ LASO, M. ${ }^{a}$ D.: "El papel como soporte del papel pintado", Actas del VI Congreso Nacional de la historia del Papel en España, Valencia, Conselleria de Cultura, Educació i Esport, 2005, pp. 89-91.

RODRÍGUEZ LASO M. a D.: "Restauración de papeles pintados "panorámicas" en el País Vasco: la caza de Compiègne”, Akobe, 3, 2002, pp. 25-27.

RODRÍGUEZ LASO, M. a D.: "Los papeles pintados en Euskadi. Paper pintatuak euskadin”, Blablart, 10, 2009.

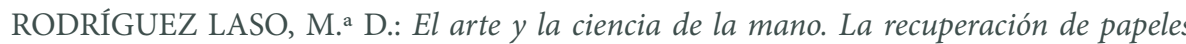
pintados históricos. Bilbao, Universidad del País Vasco, 2004.

RODRÍGUEZ LASO, M. ${ }^{a}$ D.; CANALS AROMI, M. ${ }^{\text {a T.: }}$ "Localización de papeles pintados del siglo XIX en España. Restauración del papel pintado panorámico Vistas de España”, $24 .{ }^{\circ}$ Congreso IPH, Oporto, 1998, pp. 280-286.

ROSE-DE VIEJO, I.: La Real Fábrica de Papales Pintados de Madrid (1786-1836), Madrid, Cátedra, 2015.

RUIZ ALCÓN M. ${ }^{a}$ T.: "Papeles pintados" en BONET CORREA, A.: Historia de las Artes Aplicadas e Industriales en España. Madrid, Cátedra, 1987, pp. 423-425.

RUIZ GARCÍA, P.: "Imaz y Delicado, Fábrica de papeles pintados", Boletín de la Sociedad de Amigos de la Cultura de Vélez-Málaga, 5, 2006, pp. 59-64.

SANTOYO, J. C.: La imprenta en Álava, historia, obras, documentos, Vol. II, El siglo XIX (1801-1850), Vitoria, Fundación Sancho el Sabio, 1995.

SANZ DE MIGUEL, C.: "La revalorización del Arte del papel pintado en una de las últimas manufacturas regias del Antiguo Régimen español”, Revista Historia Autónoma, n. ${ }^{\circ}$ 10, 2017, pp. 219-222.

SERDÁN Y AGUIRREGAVIDIA, E.: Vitoria, el libro de la ciudad, Vitoria, 1927, (ed Vitoria, 1985, Tradiciones alavesas, tomo X, parte III).

TEYNAC, F.; NOLOT, P.; VIVIEN, J-D.: Le monde du papier peint, París, Berger-Levrault, 1981.
THIBAUT-POMERANTZ, C.: Wallpaper, a history of style and trends, París, Flammarion, 2009.

THOMSON, H. B., (Dir.): Papiers peints, poésie des murs. Les collections du Musée national suisse, Zürich, Musée national de Suisse, 2010.

URDAIN MARTÍNEZ, C. M.: Sedes históricas de las Juntas Generales de Álava en Vitoria y Tierras Esparsas, s. XVI-XIX, Vitoria-Gasteiz, Juntas Generales de Álava, 2015.

VALLS I SUBIRA, O.: La historia del papel en España, siglos XVIII-XIX, tomo III, Barcelona, Empresa Nacional de Celulosa, 1978

VELASCO LÓPEZ, E.: Crónicas y biografías alavesas, Vitoria, imprenta provincial, 1910.

VIDAL-ABARCA, J.: "Linajes alaveses, los Escoriaza", Boletín Sancho el sabio, año XXI, Tomo XXI, 1977, pp. 279-370

VV.AA.: French Scenic wallpaper 1795-1865, Paris, Musée des arts décoratifs, Flammarion, 1990.

VV.AA.: Technique et papier peint, Bulletín de la Société Industrielle de Mulhouse, n. ${ }^{4}$ 4, 1991. 